Document downloaded from:

http://hdl.handle.net/10251/49003

This paper must be cited as:

Barrera Puerto, A.; Bonet Senach, JL.; Romero, ML.; Miguel Sosa, P. (2011). Experimental tests of slender reinforced concrete columns under combined axial load and lateral force. Engineering Structures. 33(12):3676-3689. doi:10.1016/j.engstruct.2011.08.003.

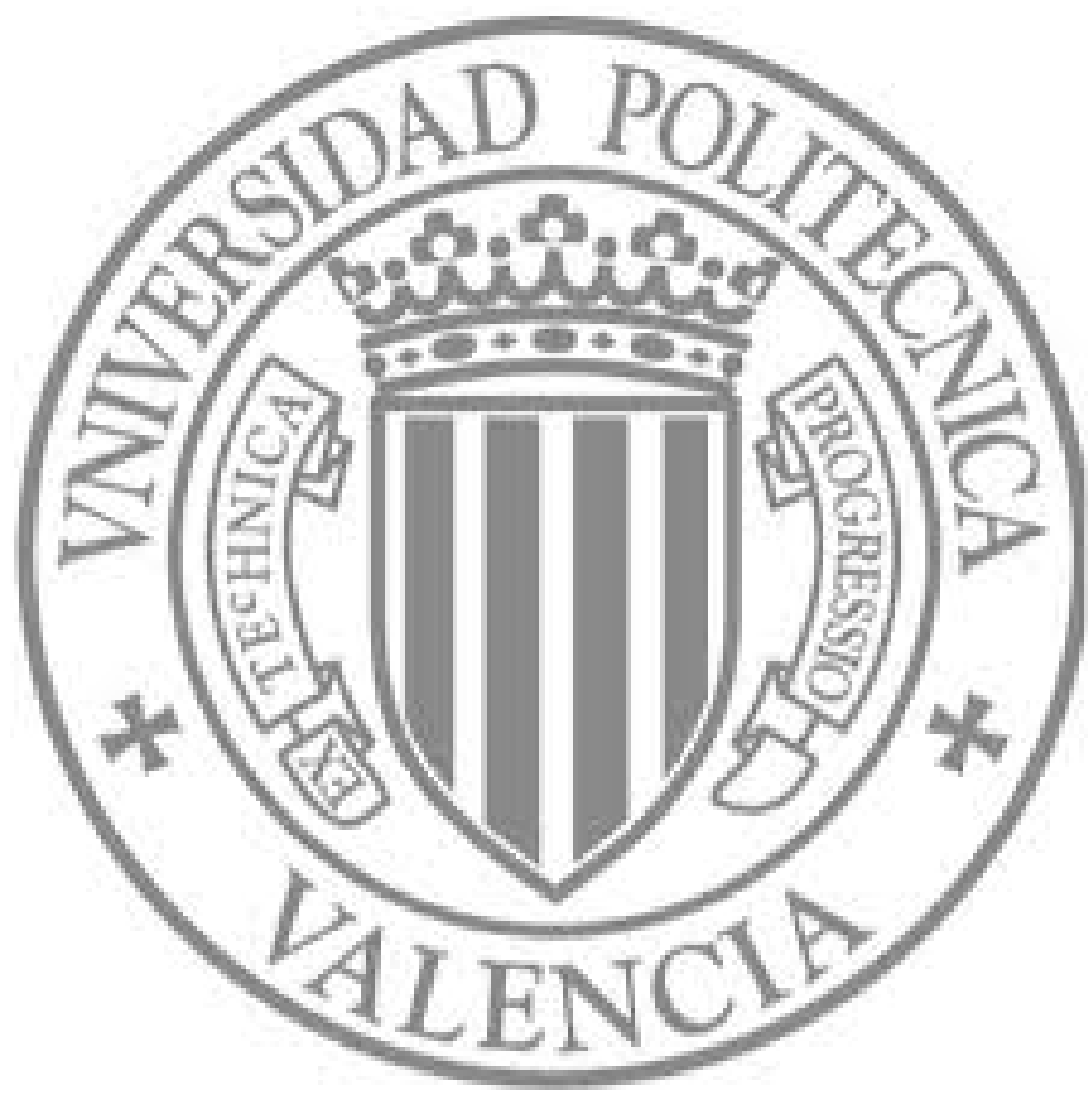

The final publication is available at

http://dx.doi.org/10.1016/j.engstruct.2011.08.003

Copyright Elsevier 


\title{
Experimental tests of slender reinforced concrete columns under combined axial load and lateral force
}

\author{
A. C. Barrera ${ }^{a}$, J.L. Bonet ${ }^{\mathrm{a}}$, M.L. Romero ${ }^{\mathrm{a}, *}$, and P.F. Miguel ${ }^{\mathrm{a}}$ \\ ${ }^{a}$ Instituto de Ciencia y Tecnología del Hormigón (ICITECH). Universitat Politècnica de \\ València, Spain
}

\begin{abstract}
The use of high strength concrete (HSC) in columns has become more frequent since a substantial reduction of the cross-section is obtained, meaning that slenderness increases for the same axial load and length, producing higher second order effects. However, the experimental tests in the literature of reinforced concrete columns subjected to axial load and lateral force focus on shear span ratios, according to Eurocode 2(2004), clause 5.6.3., $(\mathrm{M} /(\mathrm{V} \cdot \mathrm{h}))$ lower than 6.5. This gap in the literature limits technological development for the construction of these structural elements. This paper presents 44 experimental tests on reinforced concrete columns subjected to constant axial load and monotonic lateral force. The aim of this is to gain greater knowledge of the types of elements which will also be of use in calibrating the numerical models and validating the simplified methods. The test parameters are strength of concrete (normal- and highstrength concrete), shear span ratio, axial load level and longitudinal and transversal reinforcement ratio. The strength and deformation of the columns were studied, and an analysis of the simplified methods from Eurocode 2 (2004) and ACI-318 (2008) concluded that both are very conservative.
\end{abstract}

Key words: reinforced concrete, columns, experimental tests, slenderness, monotonic.

*Corresponding author: Tel: +34-963877007(ext: 76742) Fax: +34-963879679, E-mail address: mromero@mes.upv.es 


\section{NOTATION}

$\mu_{\Delta}=$ ductility ratio in displacements

$\varepsilon^{\prime}{ }_{s}=$ strain of the upper reinforcements in the section, compression.

$\varepsilon_{c l}=$ strain at peak stress of concrete

$\delta_{\text {i }}=$ displacement

$\rho_{l}=$ longitudinal reinforcement ratio.

$\delta_{\mathrm{ns}}=$ the amplification factor

$\rho_{s}=$ confinement volumetric geometric reinforcement ratio.

$\varepsilon_{\mathrm{s}}=$ strain of the lower reinforcements in the section, tension.

$\delta_{u}=$ displacement of the column in the descending branch corresponding to 0.85 of the maximum load.

$\lambda_{V}=$ shear span ratio $\left(\lambda_{V}=L_{s} / h=M /(V \cdot h)\right)$

$\delta_{y e}=$ effective elastic displacement.

$A_{s}=$ area of the longitudinal reinforcement

$\mathrm{h}=$ height of the cross section.

$\mathrm{b}=$ width of the cross section

$\omega=$ mechanical reinforcement ratio $=\left(\mathrm{A}_{\mathrm{s}} \cdot \mathrm{f}_{\mathrm{s}} / \mathrm{A}_{\mathrm{c}} \cdot \mathrm{f}_{\mathrm{c}}\right)$

$\mathrm{M}=$ bending moment

$M_{1 s t, \max }=$ maximum first order bending moment.

$M_{\max }=$ maximum total bending moment.

$\mathrm{N}=$ axial load

$N_{u c}=$ axial load for pure compression

$\mathrm{V}=$ lateral force.

$V_{\max }=$ maximum vertical load 


\section{INTRODUCTION}

In the ultimate state, the inelastic behavior of a structure is conditioned to the progressive appearance of plastic hinges, so much so that the design of the structure must aim to make yielding appear first in the beams and later in the columns in order to guarantee the overall stability (weak beam-strong column). However, in the columnfoundation connection (both for building and bridge piers) the appearance of the plastic hinge is possible in the ultimate state of the structure. Moreover, the use of high strength concrete (HSC) in columns is becoming increasingly frequent given that a substantial reduction of the cross-section is obtained, producing an increase in slenderness for the same axial load and length and resulting in higher second order effects. There are several tests in the literature (Li et al [1], Foster and Attard [2], Ho and Pam [3], Galano and Vignoli [4] among others) that demonstrate that the columns made with HSC are more brittle than NSC columns. Those authors suggest more experimental research in relation with the resistance capacity and deformation of HSC columns in order to analyze the reliability of the numerical models and simplified design methods.

From the point of view of structural safety both strength and ductility have the same significance. Traditionally, the design of structures focuses on providing the elements with enough resistance for the design forces corresponding to U.L.S (ultimate limit states) and provides enough stiffness to verify S.L.S (service limit states). In addition, the required ductility is guaranteed by specific design criteria and reinforcement arrangements defined in the different design codes: ACI-318 [1], EC-2 [6] and EC-8 [7].

These design methods are developed from the large amount of tests within the bibliography quantifying the deformation capacity of elements under flexure, both for monotonic and cyclic loads. In general, studies focusing on monotonic loads aim to 
investigate the capacity of the force redistribution for dead or live combinations of loads, whereas tests for cyclic loads study the behavior for a seismic event. As can be observed in the distribution of the 1125 tests summarized in chapter 6 of bulletin number 25 from the F.I.B. (Fédération Internationale du Béton) [8] for elements under monotonic and cyclic loads (Fig. 1.a), and from the database for PEER (Pacific Earthquake Engineering Research Center) [9] with 306 cyclic tests (Fig. 1.b), most of the experiments focus on a shear span ratio $\lambda_{V}$ lower than $6.5\left(\lambda_{V}=L_{s} / h=M /(V \cdot h)\right)$, Panagiotakos and Fardis [10], where $L_{s}$ is the distance between point of zero and maximum moment $M, V$ is the shear force and $\mathrm{h}$ is the overall depth of the cross section. There are several reasons that justify the need to study slender reinforced concrete columns subjected to constant axial load and monotonic (or cyclic) lateral force. The first of these is that the use of concrete with a higher capacity implies the construction of slender columns, while the second is that second order effects ( $\mathrm{P}-\Delta$ effect) have a major influence on the deformation capacity of the columns, Bae and Bayrak [11]. A third reason would be the scarcity of experimental tests with a shear span ratio higher than 6.5 .

This paper presents an experimental program which attempts to cover this lack of monotonic tests. The results of the tests aim to expand on the behavior of this column typology which will be of use when validating the calibration of numerical models, and later verifying the implementation of the simplified methods proposed in different design codes.

\section{EXPERIMENTAL PROGRAM}

In this experimental program forty-four rectangular columns with different sections $200 \times 150 \mathrm{~mm}, 140 \times 150 \mathrm{~mm}$ and $100 \times 150 \mathrm{~mm}$ were executed (Table 1). The lengths of the columns (L) are $3 \mathrm{~m}$ for all the specimens and these were subjected first to a 
constant axial load and later to a monotonic lateral force up to failure (Fig. 2). These specimens symbolize two semi-columns of two stories connected by a central element which represents the stiffener effect of an intermediate floor or the connection between a column and the foundation represented by the stub element. Each semi-column has a length $\left(L_{s}\right)$ of 1.5 meters between the support and the central element (stub) of which $1.32 \mathrm{~m}$ are reinforced concrete and $0.18 \mathrm{~m}$ correspond to the system representing the hinge support at each end of the specimen where the width of the stub element is $30 \mathrm{~cm}$. This type of specimen has also been used by other authors, Yamashiro and Sies [12], Ang et al [13], Priestley and Park [14] and Wang et al [15].

The test parameters were: strength of concrete $\left(f_{c}\right)$, shear span ratio $\left(\lambda_{V}=L_{s} / h\right.$ $=M /(V \cdot h))$, axial load level $\left(N / N_{u c}\right.$, where $N$ is the axial load applied and $N_{u c}$ is the axial load for pure compression), confinement volumetric geometric reinforcement ratio $\left(\rho_{s}=\right.$ $W_{s c} / W_{c}$, where $W_{s c}$ is the volume of the confinement stirrups and $W_{c}$ is the volume of the confined concrete), and the longitudinal reinforcement ratio $\left(\rho_{l}=A_{s} /(b \cdot h)\right.$, where $A_{s}$ is the area of the longitudinal reinforcement and " $h$ " is the dimension of the section perpendicular to the bending axis)

The range of variables studied is the following:

- Strength of concrete $\left(f_{c}\right): 30,60$ and $90 \mathrm{MPa}$ (nominal strength)

- Shear span ratio $\left(\lambda_{V}\right): 7.5,10.5$ and 15 .

- Axial load level: A variation between the null axial load and $45 \%$ of the ultimate axial load $\left(N_{u c}\right)$ is studied, where:

$$
N_{u c}=b \cdot h \cdot f_{c}+\sigma_{s} \cdot A_{s} \quad \sigma_{s}=\varepsilon_{c 1} \cdot E_{s} \leq f_{y}
$$

where $\varepsilon_{c l}$ is the strain at peak stress of concrete following clause 3.1 .5 of EC-2 (2004) [6]. 


$$
\varepsilon_{c 1}(\%)=0.7 \cdot f_{c}^{0.31}<2.8 \% \text { o }
$$

$E_{s}$ is the Young modulus of the longitudinal reinforcement (200 GPa)

$f_{y}$ is the yielding stress of the longitudinal reinforcement

- Confinement volumetric geometric reinforcement ratio: between $0.8 \%$ and $3.1 \%$. In all cases the anchorage of the stirrups was arranged during compression. This anchorage was defined with an angle of $90^{\circ}$ and a length of $10 \cdot \phi_{\mathrm{t}}>70 \mathrm{~mm}, \phi_{\mathrm{t}}$ being the diameter of the transversal reinforcement (Clause 8.5 from EC-2[6]).

- Longitudinal reinforcement ratio: between $1.4 \%$ and $3.2 \%$

Table 2 lists the details of the 44 tests of the experimental program. The nomenclature followed in the tests was:

$$
N / H f_{c}-\lambda_{v}-C x-\rho_{l}-N / N_{u c}
$$

where $\quad N / H f_{c} \quad$ stands for the type of concrete $(N)$ normal-, $(H)$ high-strength and $f_{\mathrm{c}}$ is the nominal strength of concrete in $\mathrm{MPa}$.

$\lambda_{V} \quad$ shear span ratio.

$\mathrm{Cx} \quad \mathrm{x}$ ' is the nominal confinement volumetric geometric reinforcement ratio in percentage.

$\rho_{l} \quad$ longitudinal reinforcement ratio in percentage.

$N / N_{u c} \quad$ axial load level.

The nominal cover of the longitudinal reinforcement $(c)$ is $0.02 \mathrm{~m}$ in tests 1 to 34 and $0.023 \mathrm{~m}$ in tests 35 to 44 (see Table 1 and Table 2).

\section{Material properties}

All columns were cast using concrete batched in the laboratory using Portland cement type CEM I 52,5R, following code UNE-EN 197-1:2000 [16]. Different additives were 
used depending on the strength of the concrete: BASF Glenium 300C with silica fume for the $90 \mathrm{MPa}$ and super-plasticizer Sika Cem for $60 \mathrm{MPa}$. The gravel used was calcareous, ranging between 4 and $7 \mathrm{~mm}$ in size, and the water-cement ratio was 0.63 for normal-strength concrete $(30 \mathrm{MPa}), 0.42$ for $60 \mathrm{MPa}$ and 0.32 for $90 \mathrm{MPa}$ respectively.

All the columns were tested at 28 days, and the concrete compressive strength ' $f_{c}$ ' was determined from $150 \times 300 \mathrm{~mm}$ cylinders using standard tests.

Table 3 presents the exact mix proportions used to manufacture each type of concrete in the experimental program, and Table 4 lists the mean values of strength of concrete obtained from the standard tests.

Four pieces of reinforcing steel B 500 SD were also tested for each diameter, where B means 'steel bars'and SD is a reference used to indicate special ductility characteristics. Fig. 3 shows the results obtained with the quality control following European Standard UNE EN-10002-1 [17] with an elastic modulus of $200 \mathrm{GPa}$.

\section{Column manufacture}

The elements were cast in a horizontal position and vibrated with a needle vibrator. After 24 hours the columns were separated from the formwork and conserved in a wet atmosphere in order to minimize the effects of shrinkage.

\section{Test setup}

A special test frame was designed in order to perform all the tests (Fig. 4.a). The horizontal system for applying the axial load is made up of two external plates and four GEWI steel bars with a diameter of $36 \mathrm{~mm}$. One of the plates is attached to a $2000 \mathrm{kN}$ load cell and the second one is fixed with the horizontal $2500 \mathrm{kN}$ hydraulic jack which leans on a sliding support to enable horizontal displacement (Fig. 4.b).

Two hinges were placed at the ends of the specimens. These steel elements are designed 
to allow the free rotation of the specimen and guarantee that the load is applied to its central axis. These hinges are supported by a special plate with rollers which enable free horizontal displacement (Fig. 4.b). The longitudinal reinforcement of each reinforced concrete column tested was welded to a piece of channel steel section. This steel section was screwed to the hinges using four embedded screws.

The set-up for applying the vertical load is attached to an auxiliary framework which transmits the vertical loads to a strong floor. This load is applied to the specimen with a different $500 \mathrm{kN}$ hydraulic jack, controlled by a $200 \mathrm{kN}$ load cell and transmitted via a special assembly (Fig. 4.c).

\section{Instrumentation.}

The strains were measured in the reinforcing bars in 9 sections of one of the semicolumns (Fig. 5- plan view). In order to ensure that the instrumented half of the column was the first to reach failure, the other semi-column was strengthened with an additional rebar both in the compressed part of the section (top) and the lower part of the crosssection (bottom) with a length higher than the potential plastic hinge length (Fig. 5, section A-A'). The strain gauges were located in the central reinforcement bar of the section both in the upper and lower arrangement (Fig. 5, section B-B'). The first instrumented section (C1) was located $2 \mathrm{~cm}$ from the stub element and the following sections (C2, C3, etc) were located each $5 \mathrm{~cm}$ or $10 \mathrm{~cm}$ (Fig. 5- plan view).

Twelve LVDTs were used to measure the lateral displacement (Fig. 6). LVDT 5 measures the displacement perpendicular to the bending plane in order to quantify geometric imperfections or the lateral instability of the column. During the tests, this effect was observed as negligible. LVDTs 3 and 4 aim to measure a possible rotation of the stub element. Again, no significant rotation was observed during the tests despite the asymmetry of the column due to the additional rebars. 
As was commented, two load cells were used to measure the axial and lateral loads applied.

\section{Test procedure}

Initially, the axial load was applied and maintained constant during the tests. Later a vertical load was applied up to failure of the column. The column was tested in a displacement control in order to measure post-peak behavior, with a view to measuring the displacement corresponding to 0.85 of the maximum vertical load $\left(V_{\max }\right)$ in the descending branch.

\section{TEST RESULTS}

Table 5 lists a summary of the observations registered in the 44 tests. It also presents the strain of the upper $\left(\varepsilon_{\mathrm{s}}^{\prime}\right)$ and lower $\left(\varepsilon_{\mathrm{s}}\right)$ reinforcements in section $\mathrm{C} 2(5 \mathrm{~cm}$ from the stub), the displacement of the critical section $(\delta)$, the type of failure (explained later), and the vertical load $(\mathrm{V})$ corresponding to the maximum lateral force and the maximum bending moment respectively. Furthermore, this table presents the ductility measured in displacements $\left(\mu_{\Delta}\right)$, which will also be defined later, and the ratio between the length of critical section and the height of the section $\left(\mathrm{L}_{\mathrm{cr}} / \mathrm{h}\right)$.

\subsection{Test observations}

The following observations can be inferred in analyzing the behavior from the tests:

- For the columns with a shear span ratio $\lambda_{V}=15$, no yielding strains were observed for either concrete or steel. Therefore, the potential plastic hinge zone is null. However, yielding strains were measured for the other specimens with a shear span ratio between 7.5 and 10.5 .

- In general, for the non-confined columns $\left(_{\rightarrow \mathrm{s}} \leq 1 \%\right)$ with normal-strength concrete, the spalling of the concrete cover was noted during failure for axial load levels $N / N_{u c}$ 
of $45 \%$. However, for the columns with $60 \mathrm{MPa}$, this spalling was observed between 30 and $45 \%$ (Fig. $7 . a$ ) and for $90 \mathrm{MPa}$ beginning with $15 \%$. Nevertheless, in all the tests with a higher confinement $(\rightarrow \mathrm{s} \geq 1.9 \%)$, for both 30 and $90 \mathrm{MPa}$, the spalling of the concrete cover appeared for $N / N_{u c} \geq 30 \%$ (Fig. 7.b). This behavior shows that the higher the strength and the axial load, and the lower the spacing between the transversal reinforcement, the more frequent the spalling of the concrete cover. As was affirmed by Collins et al [18], in specimens with HSC the spalling of the concrete cover is related to the appearance of 'splitting cracks' in the longitudinal reinforcement plane, which produce a reduction of the strength capacity of the column. Moreover, the lower spacing between the transversal reinforcement also contributes to the weakness of this area. Generally, in the confined specimens the spalling of concrete cover have not produced an important loss of the strength capacity.

- The buckling of the compressed reinforcement was observed in almost all the tests with high axial load levels $(N / N u c=45 \%$. $)$, particularly in those with a stirrup spacing of $10 \mathrm{~cm}$, and once the longitudinal reinforcing bar had yielded (Fig. 7.a). As was expected, in the columns with lower stirrup spacing this effect practically disappears (Fig. 7.b).

- For all the tests, no damage was observed in the area close to the connection between the stub and the semi-column, despite this being the section where the maximum bending moment is localized (Fig. 8.c). Other authors maintained that this effect was due to the confinement produced by the higher stiffness of the stub in nearby zones (Li et al. [19], Bayrak and Sheikh[20], Légeron and Paultre[21], Sheikh and Khory[22], Paultre et al[23], Ho and Pam [3]). This phenomenon 
increases the maximum bending moment in the areas surrounding the stub. As a result, the critical section is translated to an inside section of the semi-column.

Another way to observe this phenomenon in experiments is by means of curvature distribution (Fig. 8.a and Fig. 8.b). The curvature was obtained from the top and bottom strains of the cross-section divided by the distance between them. We observed that the maximum curvature did not appear in the section closest to stub (C1), but in the following sections (between $\mathrm{C} 2$ and C3). Consequently, C2 was selected as the critical section for the analysis of the results (Fig. 8.c).

- For the tests with pure bending (without axial load), independently of the strength of concrete, the behavior with respect to the strains of the materials and the deformed shape is similar (Fig. 9). When the vertical load is higher than the yielding load (Fig. 9.a) between sections $\mathrm{C} 1$ and $\mathrm{C} 2$, the strains in the rebars increase notably with distances (potential plastic hinges) equal to the height of the cross-section. Fig. 9.b and Fig. 9.c show the strains of the top $\left(\varepsilon_{s}^{\prime}\right)$ and bottom $\left(\varepsilon_{s}\right)$ reinforcement respectively. Furthermore, the yielding strain $\left(\varepsilon_{y}= \pm 2.65 \%\right.$ is indicated as reference. It can be observed that maximum tensile strain is not reached in the same section in terms of the applied load (V). Accordingly, although the vertical load is increased monotonically, Fig. 9.a, the deformation in the tensile reinforcement is subjected to load-unload procedures, Fig. 9.c, once the load $V_{y}$ is reached and moving the section where the tensile deformation is maximum. However, the strain of the compression reinforcement, Fig. 9.b, increases when the load increases in all sections.

In addition, for the remaining tests with a non-null axial load, it was observed that both strains are increased at the same time as lateral force $\mathrm{V}$. 
- Two typical deformed shapes were observed in the experimental program. Fig. 10.a presents the deformed shape with different states of load and failure, with yielding concentrated in a reduced length (point-hinge). This behavior is typical in the tests without axial load. In contrast, if the deformation is distributed along a potential plastic hinge length, the deformed shape corresponds to Fig. 10.b.

\subsection{Failure mode}

In order to analyze the failure mode of the overall structure the maximum vertical load state $\left(V_{\max }\right)$ is studied. The possible failure modes are: instability or section failure (tension or compression). However, if the failure mode in the section level wants to be studied, the failure for maximum total bending moment $\left(M_{\max }\right)$ will be analyzed. In this case the failure modes are due to tension or compression. Afterwards, it will be demonstrated that the type of failure is related with the behavior of the structural element.

\section{2.-1 Type of Failure for maximum vertical load $\left(V_{\max }\right)$}

It is worth noting that the maximum first order bending moment $\left(M_{1 s t \text { max }}\right)$ is in agreement with the maximum vertical load $\left(V_{\max }\right)$. The first order bending moment and the total bending moment (including second order effects) in the critical section are plotted in terms of displacement in the same graph (Fig. 11) in order to identify the failure mode for the maximum load (instability or ultimate strength of the section). In order to differentiate the failure of the specimen due the section failure (A) or instability (I), the following criterion is applied: if the first order bending moment and the total bending moment are reached simultaneously for the same displacement, the failure mode will be due to the ultimate strength of the section (Fig. 11.a), otherwise the failure will be due to instability (Fig. 11.b). 
Fig. 11 displays the strain distribution in the sections close to the stub for maximum load state $\left(M_{1^{o} \max }\right)$ and total bending moment state $\left(M_{\max }\right)$ both in the top and bottom reinforcement for two different cases of failure mode. Also the maximum strain in the concrete is presented using an extrapolation of the reinforcement following a planar deformation hypothesis.

With the aim of obtaining a more accurate failure mode for $V_{\max }$, the deformation state was analyzed for the critical section and in sections surrounding potential plastic hinges (Table 5), inferring the following failure modes:

a) The failure mode due to 'ultimate strength of the section' can be classified into two types:

- Failure due to tension: (A/T) if the most tensile reinforcement yields. Otherwise it can be classified as failure due to compression $(\mathrm{A} / \mathrm{C})$ of the concrete.

b) Instability can be classified into three types:

- If a substantial reduction of the stiffness of the column is produced: 'instability due to tension $(\mathrm{I} / \mathrm{T})$ ' caused by the yielding of the tension reinforcement ; 'instability due to compression (I/C)' caused by the yielding of the compression reinforcement; 'elastic instability (I/E)', produced without the yielding of the materials.

Table 5 lists the failure mode corresponding to the maximum load state for each test. In order to understand this behavior better Table 6 to 8 show the failure mode in terms of the different parameters studied.

It can be concluded that for all the tests with $\lambda_{V}=7.5$ the failure mode was due to the ultimate strength of the section. In most of these, it was due to compression except for 
one case with $30 \mathrm{MPa}$, axial load level (30\%), and low confinement level $\left(\rho_{\mathrm{s}} \leq 1 \%\right)$. As was expected, in specimens with pure bending (null axial load) the failure mode was due to 'tension'. In addition, instability is more frequent when the slenderness of column, axial load level or strength of concrete are increased and the longitudinal reinforcement ratio is reduced. For lower axial load levels $\left(N / N_{u c}=15 \%\right)$ instability is produced due to the yielding of the tension reinforcement, while for higher axial load levels the rebars do not yield.

\subsection{2.- Type of Failure for maximum total bending moment $\left(M_{\max }\right)$}

Likewise, the deformation state for the critical section was analyzed for the maximum total bending moment (Table 5). A further analysis of the results is presented in Table 6 to Table 8. As was expected, in specimens with null (i.e. bending) or lower axial load levels $\left(N / N_{u c}=15 \%\right)$, failure is due to tension. Compression failure is more common in proportion to the strength of the concrete, the axial load level, and an increase in the ratio of longitudinal and transversal reinforcement.

\subsection{Length of critical region}

The length of critical region of each column (Table 5) was evaluated by the physical observation method proposed by Pam and Ho [24], Fig. 8. The $l_{c r} / h$ ratio is close to the half of the height of the cross-section in those specimens subjected to pure bending (without axial load). In these tests the cracking is vertical with a slight inclination in the compressed part of the concrete.

In the tests with axial load and where the failure mode in maximum bending moment is due to tension $(\mathrm{A} / \mathrm{T})$, we can observe a zone with vertical cracks with a separation equal to the stirrup spacing. In general, the spalling of the concrete cover was not observed in these tests. 
In the non-confined columns $(\rightarrow s \leq 1 \%)$ under axial load and lateral force and where the failure mode for maximum bending moment is due to compression $(\mathrm{A} / \mathrm{C})$ a spalling of the concrete cover was observed, with a cracked area as high as the cross-section.

In all the non-confined specimens $(\rightarrow \mathrm{s} \leq 1 \%)$ with higher axial load $\left(N / N_{u c}=45 \%\right)$, the damaged area reaches between 1 and 2 times the height of the cross-section. In these cases the degradation of the concrete is higher than for the previous cases and buckling of the compressed reinforcement is frequent (Fig. 7.a).

Finally, in the confined columns $(\rightarrow \mathrm{s} \geq 1.9 \%)$, buckling of the compressed reinforcement is not observed, although considerable spalling was observed (including on the sides, Fig. 7.b). Also a fan-shaped inclined distribution of cracks was observed in a wide zone which can reach between 1 and 2.5 times the height of the cross-section. It can be concluded that the 'length of critical region' depends on the type of failure of the column, which is dependent on the axial load level, the strength of concrete, and the longitudinal and transversal reinforcement ratios. One possible justification of the increment of the length of critical region with the axial load level is the lower inclination of the compressed struts of concrete with respect to axis of the element $\left(\theta \leq 45^{\circ}\right)$, regarding the pure bending case where the angle is $45^{\circ}$, and for confined elements $(\rightarrow \mathrm{s} \geq 1.9 \%)$, it can be due to the increment of the ultimate deformation of the concrete with the confinement ratio, what enables to reach a higher deformation both in the steel and concrete with a higher length of the specimen without achieving the ultimate state. Some authors, such as Pam and Ho [24], Paultre et al [23] and Bae and Bayrak [25], have verified that this length depends on the applied axial load level. However, different authors like Mendis [26] and Priestley and Park [14] point out that this length is not dependent on the axial load level.

\subsection{Strength.}


Table 5 presents the lateral force $(\mathrm{V})$ corresponding to the maximum load and the maximum bending moment for each test.

Regarding the maximum load, and as expected, the lateral force $V_{\max }$ increases with the strength of concrete and the longitudinal reinforcement ratio and with lower values of the slenderness of the column.

It can be observed that with $\lambda_{V}=7.5$ the maximum lateral force is reached for an axial load level $\left(N / N_{u c}\right)$ of $30 \%$, whereas for $\lambda_{V}=10.5$ it is reached for a $\left(N / N_{u c}\right)$ of $15 \%$.

\subsection{Deformation Capacity}

With the aim of comparing the different ductility levels reached in the tests, a ductility factor in displacements $\left(\mu_{\Delta}\right)$ is introduced as:

$$
\mu_{\Delta}=\frac{\delta_{u}}{\delta_{y e}}
$$

where: $\delta_{u}$ is the displacement of the column in the descending branch corresponding to 0.85 of the maximum load (Wang et al[15], Panagiotakos and Fardis [10], fib Bulletin 25 [8], Hwang and Yun [27], Verderame et al [28][29]). A higher reduction of the load, for instance $20 \%$, was not generally reached in the columns, (Eurocode 8 (EN 19982:2005)[7], Fardis and Biskinis [30])

$\delta_{y e} \quad$ is the effective elastic displacement.

In tests where it was not possible to obtain a $15 \%$ reduction of the maximum load, the maximum displacement was used $\left(\delta_{u}\right)$.

In order to obtain the effective elastic displacement it is necessary to resolve the yielding point in an experimental force-displacement diagram. This situation can be due 
to two factors: because of the yielding of the steel due to tension or due to the beginning of nonlinear behavior of the concrete. For these tests tension reinforcement yields if the strain $\varepsilon_{s}$ is lower than $-2.65 \%$. However there are many criteria affecting the definition of strain arising from the nonlinear behavior of concrete.

Paulay and Priestley [31] accept a strain of $1.5 \%$ as reference, Panagiatakos and Fardis [10] and Fardis and Biskinis [30] admit the strain $0.90 \cdot f_{\mathrm{c}} / E_{\mathrm{c}}$, as reference where $E_{\mathrm{c}}$ is the elastic modulus of concrete, and the fib Bulletin 24 [32] points out that nonlinearity starts when strain is $0.75 \cdot \varepsilon_{\mathrm{c} 1}$, where $\varepsilon_{\mathrm{c} 1}$ is the ultimate deformation of the concrete following EC-2 [6] (see equation 2). This last criterion is accepted for this paper.

If the experimental force-displacement relationship is represented in an elastic-plastic diagram according to Eurocode 8 (EN 1998-2:2005 Annex E.3.2) [7], the effective elastic displacement can be deduced, $\delta_{y e}$ (Fig. 12). The energy balance is performed starting from the yielding point, well due to the yielding of the steel or well to the beginning of the nonlinear behavior of concrete. Table 5 presents the ductility obtained in displacements. Table 9 to Table 11 show the influence of different parameters on ductility. In the columns with $\lambda_{V}=7.5$, ductility decreases when the axial load level increases, while in tests with $\lambda_{V}=10.5$ maximum ductility is reached for an $N / N_{u c}=$ $30 \%$. With respect to the influence of the longitudinal reinforcement, increased reinforcement improves ductility if the failure is due to tension, otherwise, if the failure is due to compression the ductility decreases.

In the analyzed columns it was inferred that the ductility $\left(\mu_{A}\right)$ does not always decrease with the axial load level. Fig. 13 shows the results for the specimens with $\lambda_{V}=10.5$ and $\mathrm{fc}=90 \mathrm{MPa}$ without confinement. It can be observed that both the displacement $\delta_{u}$ and $\delta_{y e}$ decreases with the axial load level. Thus, for null axial load the yielding corresponds to the steel yielding $\left(\varepsilon_{s}=-2.65 \%\right.$. $)$, while for higher axial load levels it corresponds to 
the yielding of concrete $\left(0.75 \cdot \varepsilon_{c l}\right)$, therefore, it will be produced for a lower displacement. Consequently, as the effective elastic displacement also decreases with the axial load, the ductility does not always decrease with the axial load level.

However, previous research (Légeron and Paultre [21]; Wang et al[15]; Bayrak and Sheikh [20], Bae and Bayrak[11]) demonstrated that ductility effectively decreases with the axial load level. In these tests the specimens had a slenderness $\lambda_{V}$ lower than 6 , and the second order effects were not significant.

Finally, in the cases where the slenderness is increased from 7.5 to 10.5 , and for the axial load levels $\left(N / N_{u c}\right)$ of 30 and $45 \%$, the ductility $\left(\mu_{A}\right)$ increases (Fig. 14). Although second order effects decreased notably, the ductility increased due to the effective elastic displacement $\left(\delta_{y e}\right)$, which is similar for both cases. The ultimate displacement $\left(\delta_{u}\right)$ is higher in the slender specimens due to their higher flexibility. Evidently, as it was affirmed by Menegotto [33], the decrease of the second order effects reduce the strength capacity of the column and the dissipated energy ( $W=\int V d \delta$, where $V$ is the lateral load and $\delta$ the displacement). The effect of the slenderness and the axial load level on ductility requires more extensive study as few tests have been carried out on specimens with a shear span ratio higher than 6 .

\section{VERIFICATION OF THE SIMPLIFIED METHODS}

A comparison between the experimental results and the proposed methods from ACI318(08) [1] and EC-2 (2004) [6] was performed.

The standard ACI-318 [1] suggests a method for establishing the amplification factor for first order bending moment for non-sway columns. To take into account the second order effects, this method proposes the following factor: 


$$
\delta_{n s}=\frac{C_{m}}{1-\phi \cdot \frac{N}{N_{c r}}}
$$

where $C_{m}$ is an equivalent factor that depends on the bending moment distribution; $\phi$ is a reduction factor for the strength, which is assumed to be one for this study; $\mathrm{N}$ is the applied axial load in the column; $N_{c r}$ is the Euler critical axial load and is equal to $\pi^{2} \cdot E I / l_{p}^{2}$ where $E I$ is the flexure stiffness of the column and $l_{p}$ is the buckling length. The stiffness $E I$ of the column is obtained using equation 10.14 from code ACI-318 (08) [1]. To obtain the Young modulus of the concrete the following expression is adopted: $E_{c}=4700 \cdot \sqrt{f_{c}}\left(f_{c}\right.$ in $\left.\mathrm{MPa}\right)$.

To apply the method, the semi-column is converted into a cantilever element with a length of $1.5 \mathrm{~m}$. (Fig. 2), the buckling length $l_{p}$ is equal to $3 \mathrm{~m}$, and the $C_{m}$ coefficient is equal to one.

The method proposed by Eurocode 2, EC-2 (2004) [6] suggests taking second order effects into account together with the amplification factor of the first order bending moments (clause 5.8.7.3 EC-2 (2004) [6]):

$$
\delta_{n s}=1+\frac{\beta}{N_{c r} / N-1}
$$

where: $\beta=\pi^{2} / 12$ for the case of lateral load (triangular bending moment distribution). The stiffness $E I$ of the column is obtained from the equation 5.21, clause 5.8.7.3. Eurocode 2[6].

The elastic modulus of the concrete is obtained using the following equation:

$$
E_{c d, e f f}=E_{c m} /\left\{\gamma_{c E} \cdot\left(1+\varphi_{e f f}\right)\right\}
$$

where: $\gamma_{c E}$ safety coefficient equal to 1.2. But in this experimental analysis a value of ' 1 ' is adopted.

$E_{c m}$ the secant modulus of deformation of the concrete: 


$$
E_{c}=22000 \cdot\left(f_{c m} / 10\right)^{0.3}\left(f_{c m} \text { in } \mathrm{MPa}\right)
$$

$f_{c m} \quad$ mean strength of concrete, which in the experiments is equal to the one obtained through the standard tests $\left(f_{c}\right)$ for each specimen.

$\varphi_{\text {eff }}$ equivalent creep coefficient. A null value is adopted in this study.

To obtain the ultimate bending moment in the cross-section using code ACI-318(08) [1] the equivalent rectangular block stress-strain is adopted (clause $10.3 \mathrm{ACI}-318$ [1]). If EC-2 [6] is used, the equivalent parabola-rectangle stress-strain is adopted (clause 3.1.7 EC-2 [6]). The values of safety factor $\gamma_{c}$ and the sustained loads coefficient are assumed to be ' 1 ' for experiments.

Table 12 lists the results obtained using the two simplified methods for the experimental tests, both for maximum load $V_{\max }$ and for maximum bending moment $M_{\max }$. The weight of the specimen was subtracted from the value of the maximum bending moment and the maximum vertical load. For some tests it was not possible to obtain the maximum load $V_{\max }$ with the simplified method because the axial load applied in experiment $N$ was higher than the critical axial load of the simplified method. The error of the methods is evaluated as the ratio between the values measured in the experiment and that obtained with the simplified method, in such a way that a value higher than one is on the safe side. Table 13 studies the error in terms of the different parameters of the study.

It can be inferred that the results obtained with both design codes are on the safe side both for $V_{\max }$ and $M_{\max }$. The method proposed ACI-318 [1] is more conservative than that proposed in EC-2 [6]. The variation coefficient (V.C.) for maximum load is much higher than the maximum bending moment.

Regarding the maximum load state, using EC-2 [6], an average error of 1.4 and a variation coefficient of $30.86 \%$ are obtained. Using ACI-318 [1] the average error is 
2.02 and the variation coefficient is $69.62 \%$. Both methods are very safe and the variation coefficient is very high. EC-2 [6] increases safety by means of concrete strength and axial load level (Table 13). It also improves slightly with confinement and has no variation for shear span ratios of 7.5 or 10.5. No trend was observed in terms of the longitudinal reinforcement ratio. Regarding ACI-318 [1], the conclusions are similar to those obtained for EC-2 [6].

As regards the maximum bending moment case, using EC-2 [6] an average error of 1.16 and a variation coefficient of $8.01 \%$ were obtained. With ACI-318 [1] the average ratio is 1.22 and $10.66 \%$ the variation coefficient. With both methods there are no representative differences for the different parameters analyzed.

As a degree of accuracy is achieved for the maximum bending moment using EC-2 [6] and ACI-318 [1], it is inferred that any loss of accuracy when calculating $V_{\max }$ in these methods is due to the amplification factor $\left(\delta_{n s}\right)$ or the equivalent coefficient $\left(C_{m}\right)$. The accuracy of the amplification factor is seriously affected by the determination of the effective stiffness of the column 'E.I'. Such parameter depends on the cracking, the creep, the nonlinear behavior of materials, etc. Moreover, due to the applied simplified method did not propose a new equation to obtain the equivalent coefficient $\left(C_{m}\right)$ for triangular bending moment distributions, if a value equal to one is adopted it produces very conservative designs.

\section{CONCLUSIONS}

The paper presents 44 experimental tests of reinforced concrete columns subjected to constant axial load and a monotonic lateral force. The test parameters are the strength of concrete (NSC and HSC), shear span ratio, axial load level, the confinement volumetric geometric reinforcement ratio and the longitudinal reinforcement ratio. Conclusions 
were drawn regarding the strength and deformation capacity of the columns and the behavior for maximum vertical load and maximum bending moment were described.

The following conclusions can be summarized:

1. Spalling of the concrete cover was observed in the state of maximum bending moment. This phenomenon is more evident for lower axial load levels $\left(N / N_{u c}\right)$ as the strength of concrete increases. Thus for $30 \mathrm{MPa}$ it appears for $N / N_{u c}=45 \%$ while for $90 \mathrm{MPa}$ it starts from $N / N_{u c}=15 \%$. Furthermore, while the spacing of the transversal reinforcement is lower, this effect is more common. This behavior implies a reduction of the strength capacity and it is important to take this into account in the numerical models.

2. It was verified that the area of connection between the semi-column and the central element (stub) was undamaged. This phenomenon is called 'stub effect'.

3. A criterion to identify the failure mode was defined, based on the analysis of the first order and total bending moments in terms of displacements, combining the study of the state of deformation of materials in the critical sections. Five types of failure modes were defined: instability (elastic, or due to tension or compression), and ultimate strength of the section (due to tension or due to compression). It was demonstrated that in the maximum load state, the lower slender columns $\left(\lambda_{V}=7.5\right)$ failed due to 'ultimate strength of the section', while failure due to compression is more common if the strength of concrete increases. For the medium slenderness specimens $\left(\lambda_{V}=10.5\right)$, instability is more common if the axial load level and the strength of concrete increase and the longitudinal reinforcement ratio decreases. The failure mode is independent of the transversal reinforcement ratio. Regarding the maximum bending moment state, as was expected, failure due to compression is 
more common if the strength of concrete, the axial load level, and the longitudinal and transversal reinforcement ratio increase.

4. The development of yielding strains in the materials (steel or concrete) depends on the failure mode of the column. Thus, for the slender specimens $\left(\lambda_{V}=15\right)$ the failure mode is due to elastic instability without major deformation in the materials, and the potential plastic hinge length has a null value. However, the rest of the specimens $\left(\lambda_{V}=7.5\right.$ and 10.5$)$ have presented yielding strains.

5. The potential plastic hinge length depends on the failure mode in the maximum bending moment state. Thus, if the failure mode is due to tension, the length is approximately equal to the height of the cross-section. However, if it is due to compression, this length depends on the axial load level and the transversal reinforcement ratio. In the non-confined specimens $(\rightarrow s \leq 1 \%)$, if the axial load is null it is equal to $\mathrm{h} / 2$ and if the axial load level $N / N_{u c}$ under compression is lower or equal to $30 \%$, this length is equal to the height of the cross-section, but if it is higher it varies between one and two times the height. Finally, for the confined columns $(\rightarrow \mathrm{s}$ $\geq 1.9 \%$ ) this length varies from 1 to 2.5 times the height of the cross-section.

6. The deformation capacity of the section was studied using ductility defined in displacements. Different criteria were adopted to fix the definition of the yielding load, the ultimate displacement and a representation of a force-displacement relationship was adopted from Eurocode 8 (EN 1998-2:2005 Annex E.3.2) [7]. It was inferred that the ductility decreases as the confinement factor and the slenderness diminish, in opposition to the strength of concrete. Ductility improves with the increase in longitudinal reinforcement if the failure is due to tension.

7. In the tests analyzed, it was verified that the ductility in displacements $\left(\mu_{\Delta}\right)$ does not always decrease with the axial load level. The analysis of the influence of 
slenderness and axial load level require further studies as few tests have been carried out for a shear span ratio higher than 6 .

Finally, it was demonstrated that EC-2 [6] and ACI-318 (08)[1] are safe both for the maximum bending moment and the maximum load states, and that the latter is more conservative. In the maximum bending moment state both methods are more accurate while they are very conservative for the maximum load state. Such loss of accuracy may be due to amplification factor $\delta_{n s}$ or equivalence $C_{m}$.

\section{ACKNOWLEDGEMENTS}

The authors wish to express their sincere gratitude to the Spanish Ministry of Science and Innovation for help provided through project BIA2009-10207 and to the European Union for financial support from Feder funds.

\section{REFERENCES}

[1] Li B, Park R, Tanaka H, Effect of confinement on the behaviour of high strength concrete columns under seismic loading, Proceeding Pacific Conference on Earthquake Engineering 1997, New Zealand, 67-78.

[2] Foster SJ, Attard MM, Experimental tests on eccentrically loaded high-strength concrete columns, ACI Structural Journal 1997; 94(3): 295-302.

[3] Ho JCM, Pam HJ. Inelastic design of low-axially loaded high-strength reinforced concrete columns. Engineering Structures 2003; 25(8): 1083-1096.

[4] Galano L, Vignoli A, Strength and ductility of HSC and SCC slender columns subjected to short-term eccentric load, ACI Structural Journal 2008; 105(3):259269.

[5] ACI 318-08. Building Code Requirements for Reinforced Concrete. American Concrete Institute, Detroit, 2008, pp 471. 
[6] CEN. EN 1992-1-1. Eurocode 2: Design of concrete structures- Part 1: General rules and rules for buildings. Brussels, Belgium: Comité Européen de Normalisation; 2004.

[7] CEN. EN 1998-1-2. Eurocode 8: Design of structures for earthquake resistance Part 2 Bridges. Brussels, Belgium: Comité Européen de Normalisation; 2005, pp 146.

[8] CEB-FIP, Bulletin 25, "State of art report (Displacement -based seismic design of reinforced concrete buildings)", Task Group 7.2, May 2003, Lausanne- Switzerland.

[9] Berry M, Parrish M, Eberhard M., PEER Structural Performance Database User's Manual, (www.ce.washington.edu/ peera1), Pacific Earthquake Engineering Research Center, University of California, Berkeley, 2004.

[10] Panagiotakos TB, Fardis MN. Deformations of reinforced concrete members at yielding and ultimate, ACI Journal Structural 2001; 98(2): 135-148.

[11] Bae S, Bayrak O, Seismic Performance of Reinforced Concrete Columns: P- $\Delta$ Effect, ACI Special Publication 2006; 236(1): 61-80.

[12] Yamashiro R., Sies CP. Moment-Rotation Characteristics of Reinforced Concrete Members Subjected to Bending, Shear, and Axial Load. Civil Engineering Studies, Structural Research series № 260; University of Illinois; Urbana, Illinois: 1962.

[13] Ang BG, Priestley MJN, Park R. Ductility of reinforced concrete bridge piers under seismic loading, Department of Civil Engineering Research Report 81-3, University of Canterbury, 1981.

[14] Priestley MJN, Park R. Strength and ductility of concrete bridge columns under seismic loading. ACI Struct J 1987; 84: 61-76. 
[15] Wang Q, Zhao G, Lin L. Effect of axial load ratio and stirrups volume ratio on ductility of high-strength concrete columns, ACI Special Publication 149-24, October 1, 1994, pp 433-448.

[16] UNE-EN 197-1:2000. Cemento - Parte 1: Composición, especificación y criterio de conformidad para cementos comunes. Asociación española de normalización y certificación, AENOR. December 2000 (in Spanish).

[17] UNE-EN 10002-1. Metallic materials. Tensile testing. Part 1: Method of test at ambient temperature. AENOR. Spanish Association for Standards and Certification; July 2002 (in Spanish).

[18] Collins MP, Mitchel D, Macgregor JG. Structural Design Considerations for HighStrength Concrete, Concrete International 1993; May: 27-34.

[19] Li B, Park R, Tanaka H. Strength and Ductility of Reinforced Concrete Members and Frames Constructed Using High Strength Concrete. Research Report No. 94-5, Department of Civil Engineering, University of Canterbury, Christchurch, New Zealand, 1994, p. 373.

[20] Bayrak O, Sheikh SA. High-Strength concrete columns under simulated earthquake loading. ACI Structural Journal 1997; 94(6): 708-722.

[21] Légeron F, Paultre P. Behavior of High-Strength Concrete Columns under Cyclic Flexure and Constant Axial Load. ACI Structural Journal 2000; 97(4): 591-601.

[22] Sheikh SA, Khoury SS. Confined concrete columns with stubs, ACI Structural Journal 1993; 90(4): 414-430.

[23] Paultre P, Legeron F, Mongeau D. Influence of concrete strength and transverse reinforcement yield strength on behavior of high-strength concrete columns. ACI Struct J 2001; 98(4):490-501. 
[24] Pam HJ, Ho JCM. Length of critical region for confinement steel in limited ductility high-strength reinforced concrete columns. Engineering Structures 2009; 31(12): 2896-2908

[25] Bae S, Bayrak O. Plastic hinge length of reinforced concrete columns. ACI Struct J 2008; 105(3): 290-300.

[26] Mendis P. Plastic Hinge Lengths of normal and high-strength concrete in flexure. Advances in Structural Engineering 2001; 4(4): 189-195.

[27] Hwang S.K, Yun HD. Effects of transverse reinforcement on flexural behaviour of high-strength concrete columns. Engineering Structures 2004; 26(1): 1-12.

[28] Verderame GM, Fabbrocino G, Manfredi G. Seismic response of R.C. columns with smooth reinforcement. Part II: Cyclic tests. Engineering Structures 2008; 30(9): 2289-2300.

[29] Verderame GM, Fabbrocino G, Manfredi G. Seismic response of R.C. columns with smooth reinforcement. Part I: Monotonic tests. Engineering Structures 2008; 30(9): 2277-2288.

[30] Fardis MN, Biskinis DE. Deformation capacity of r.c. members, as controlled by flexure or shear. In: Performance based engineering for earthquake resistant reinforced concrete structures. A Volume Honoring Shunsuke Otani, Kabeyasawa T, Shiohara H, editors. University of Tokyo. 2003. pp 511-30.

[31] Paulay T, Priestley MJN. Seismic design of reinforced concrete and masonry buildings. Ed. A Wiley Interscience Publication John Wiley \& Sons, Inc. 1992, p. 743.

[32] CEB-FIP, Bulletin 24, "Seismic assessment and retrofit of reinforced concrete buildings", Task Group 7.1, May 2003, Lausanne- Switzerland. 
[33] Menogotto, M, ULS of buckling. Comité Euro-internacional du beton: Structural Concrete, Textbook on behaviour, Design and Performance Updated knowledge of the CEB/FIP Model Code 1990, FIB 1999, 225-240. 


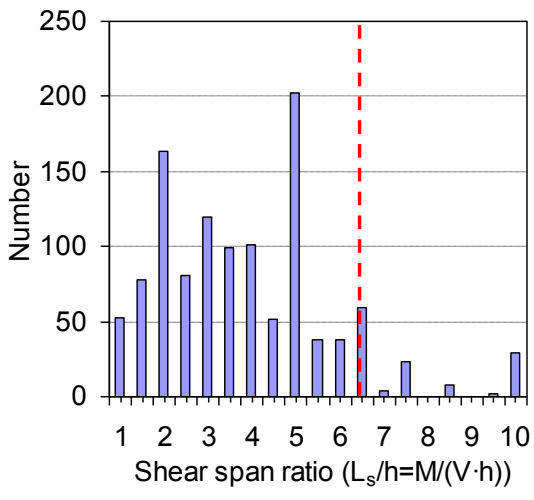

(a)

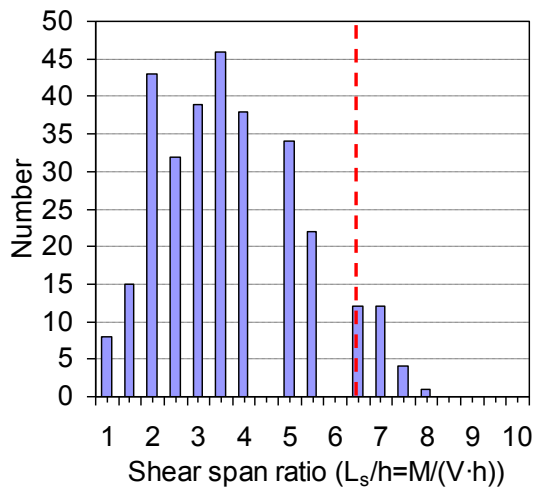

(b)

Fig. 1. Distribution of tests in the literature a) Bulletin $n^{0} 25$ from FIB [8] b) PEER [9]. 


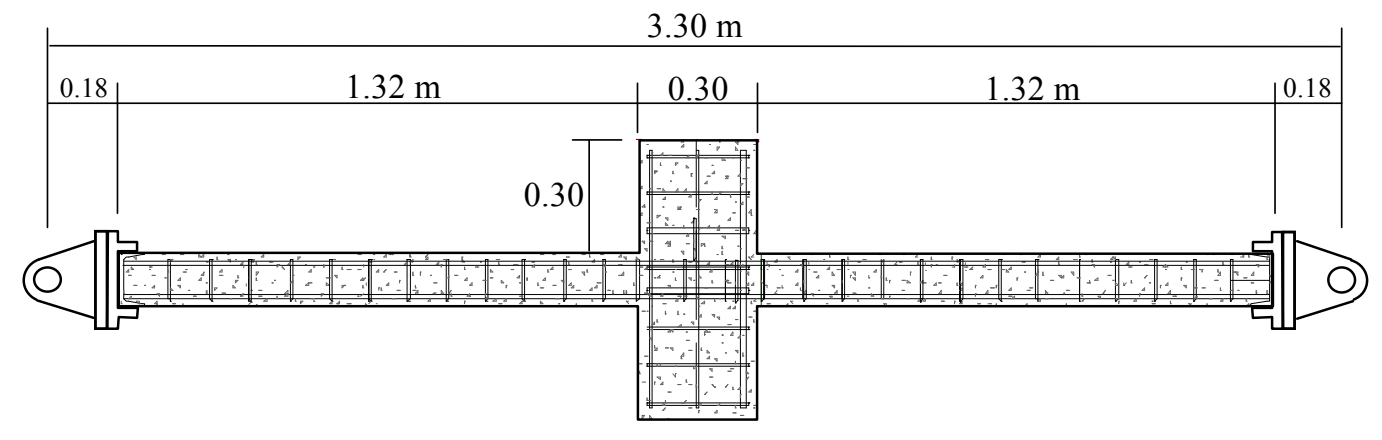

Fig. 2. Geometry of the specimen. 


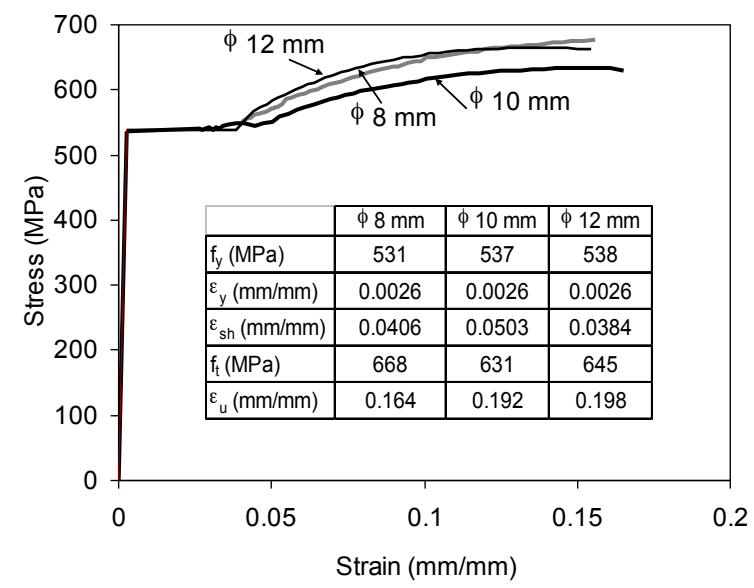

Fig. 3. Stress - strain behavior of reinforcing steel 


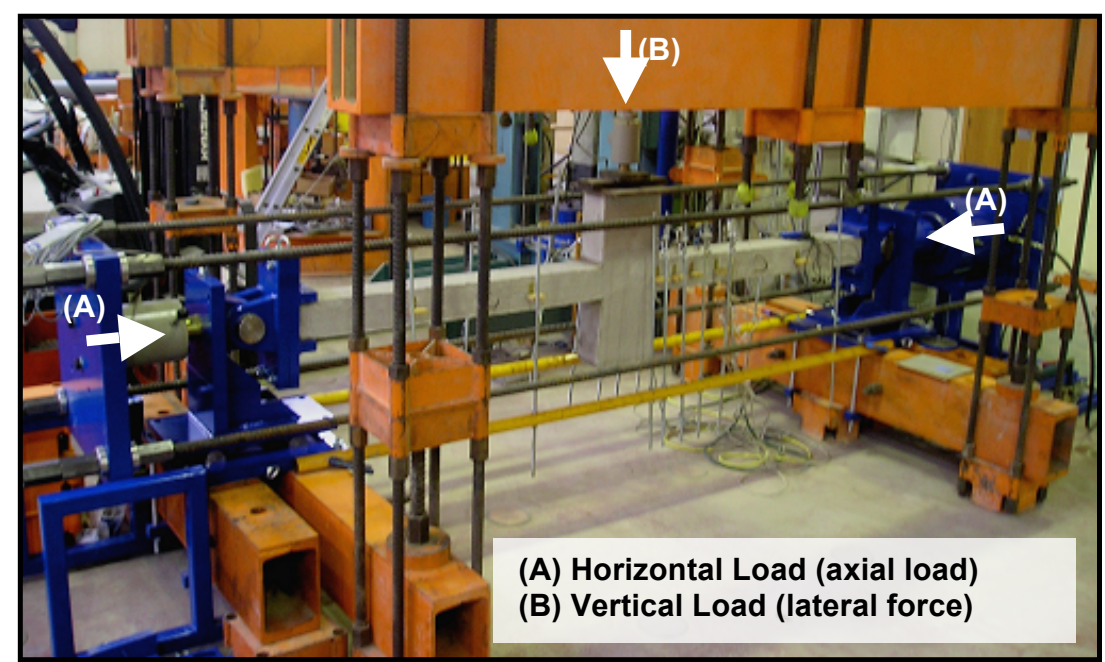

(a)

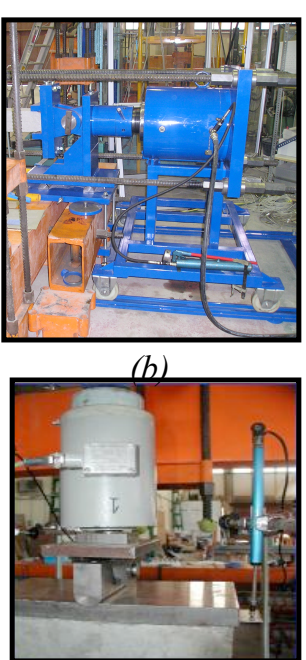

(c)

Fig. 4. Test Framework. 


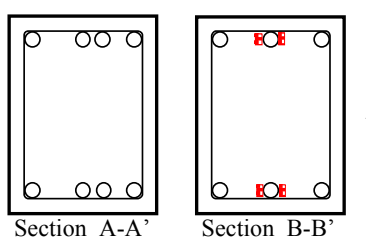

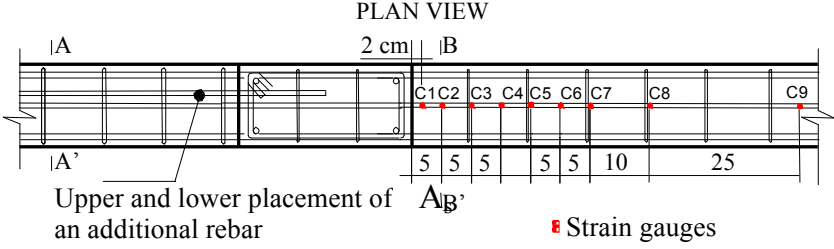

Fig. 5. Arrangement of strain gauges. 


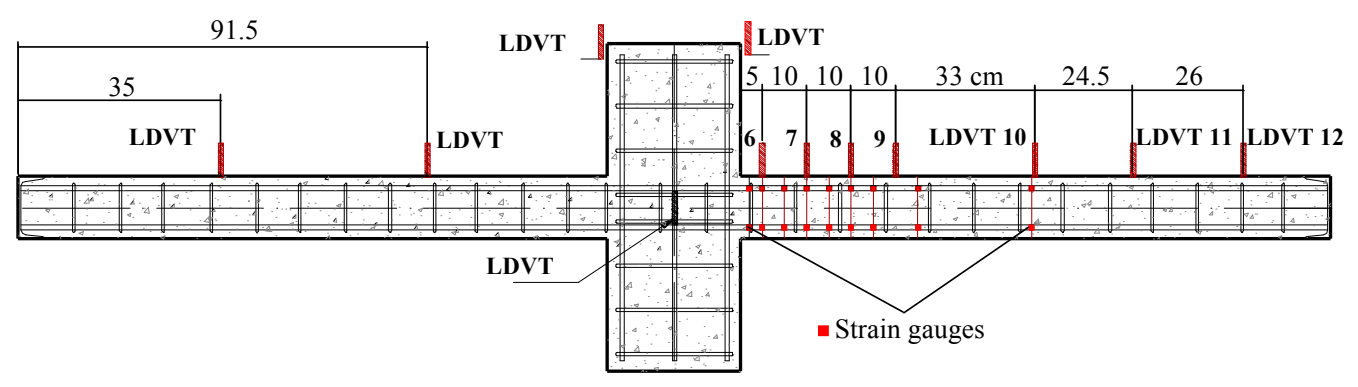

Fig. 6. Arrangement of the LVDTs 


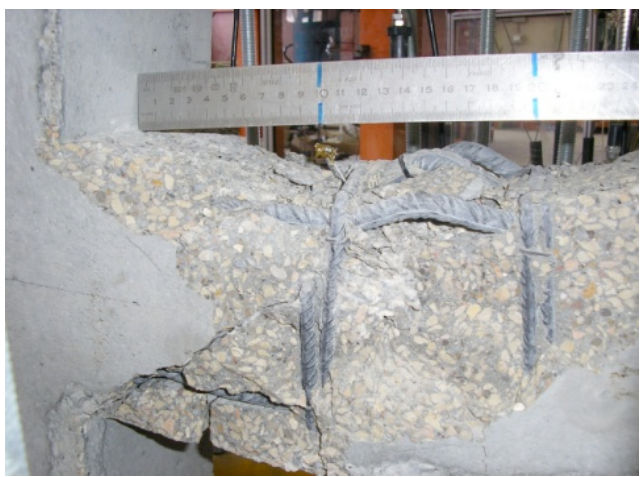

(a)

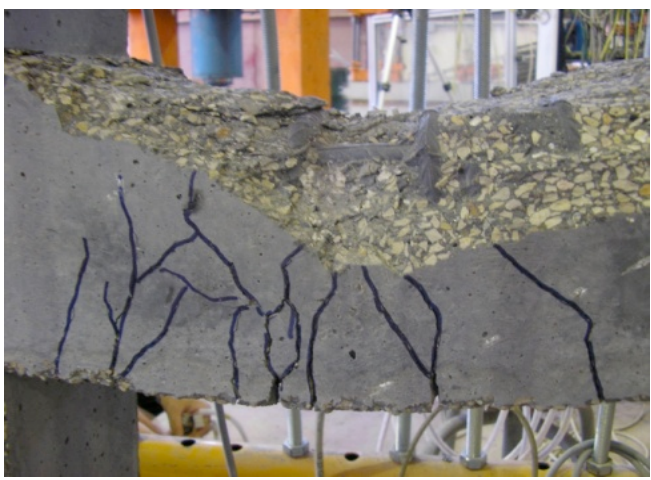

(b)

Fig. 7. Spalling of concrete cover: (a) Non-confined column $(\rightarrow \mathrm{s} \leq 1 \%)(\mathrm{H} 60-10.5-\mathrm{C} 0$ 2-45) (b) confined column (H90-10.5-C3-2-45) 


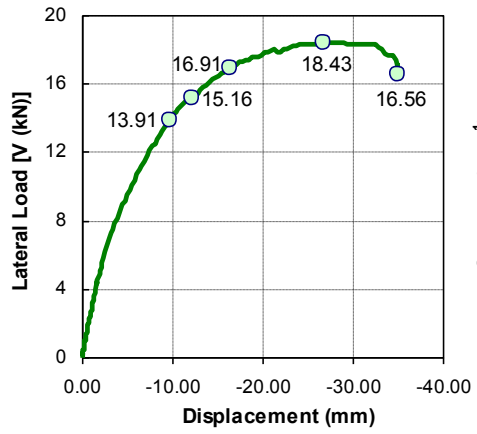

(a)

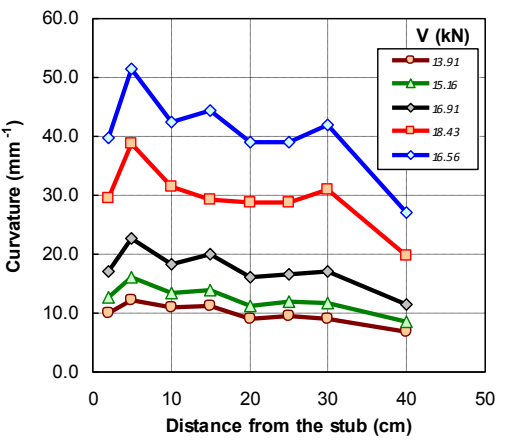

(b)

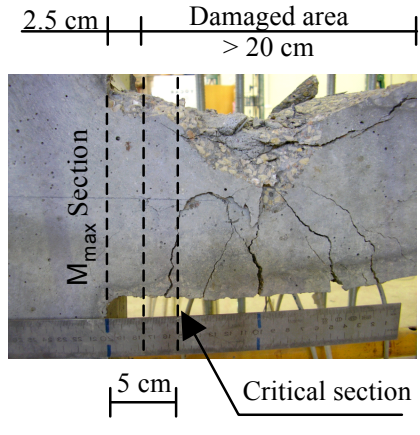

(c)

Fig. 8. Results of column H60-10.5-C0-2-30 (a) Load- displacement (b) Curvature distribution(c) 'Stub'stiffener effect 


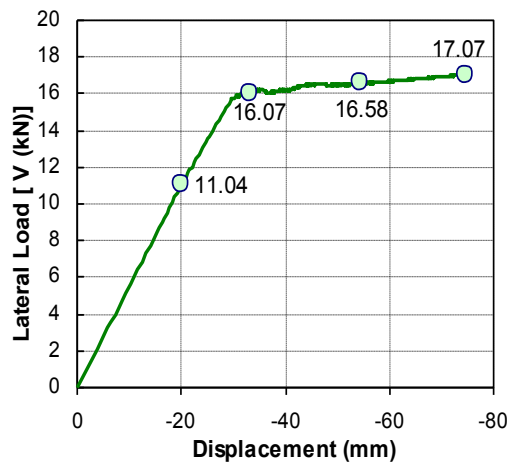

(a)

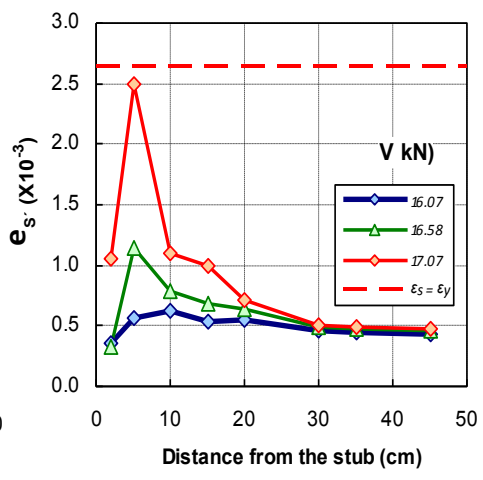

(b)

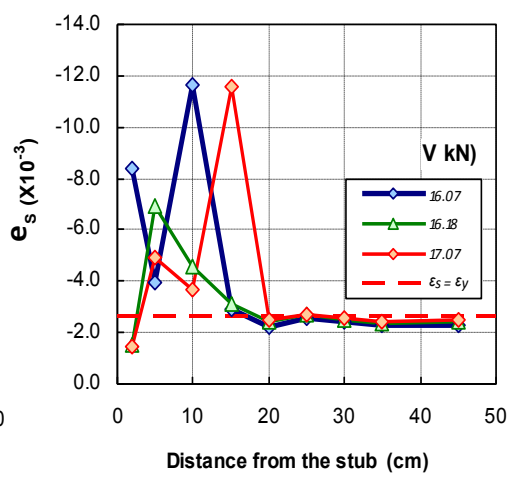

(c)

Fig. 9. Results of the column N30-10.5-C0-2-00 (a) Load-displacement (b) Strain of the top reinforcement (c) Strain of the bottom reinforcement 


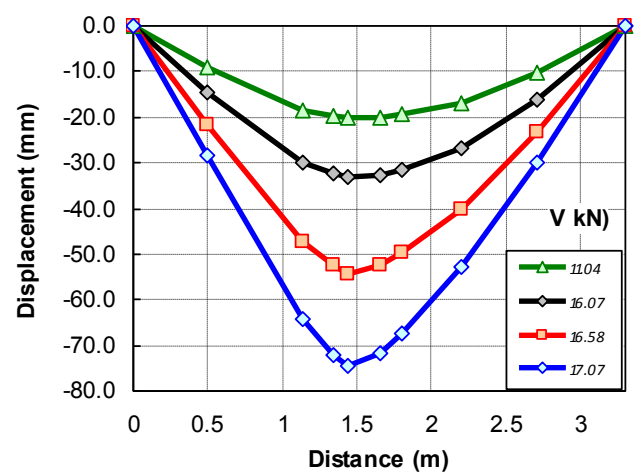

(a)

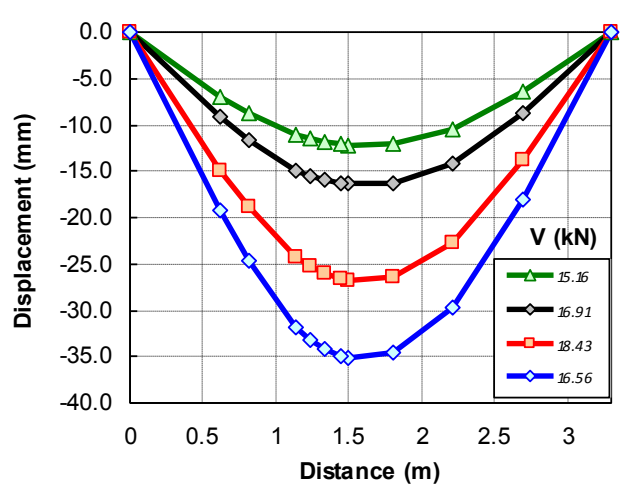

(b)

Fig. 10. Deformed shapes (a) N30-10.5-C0-2-00 (b) H60-10.5-C0-2-30 

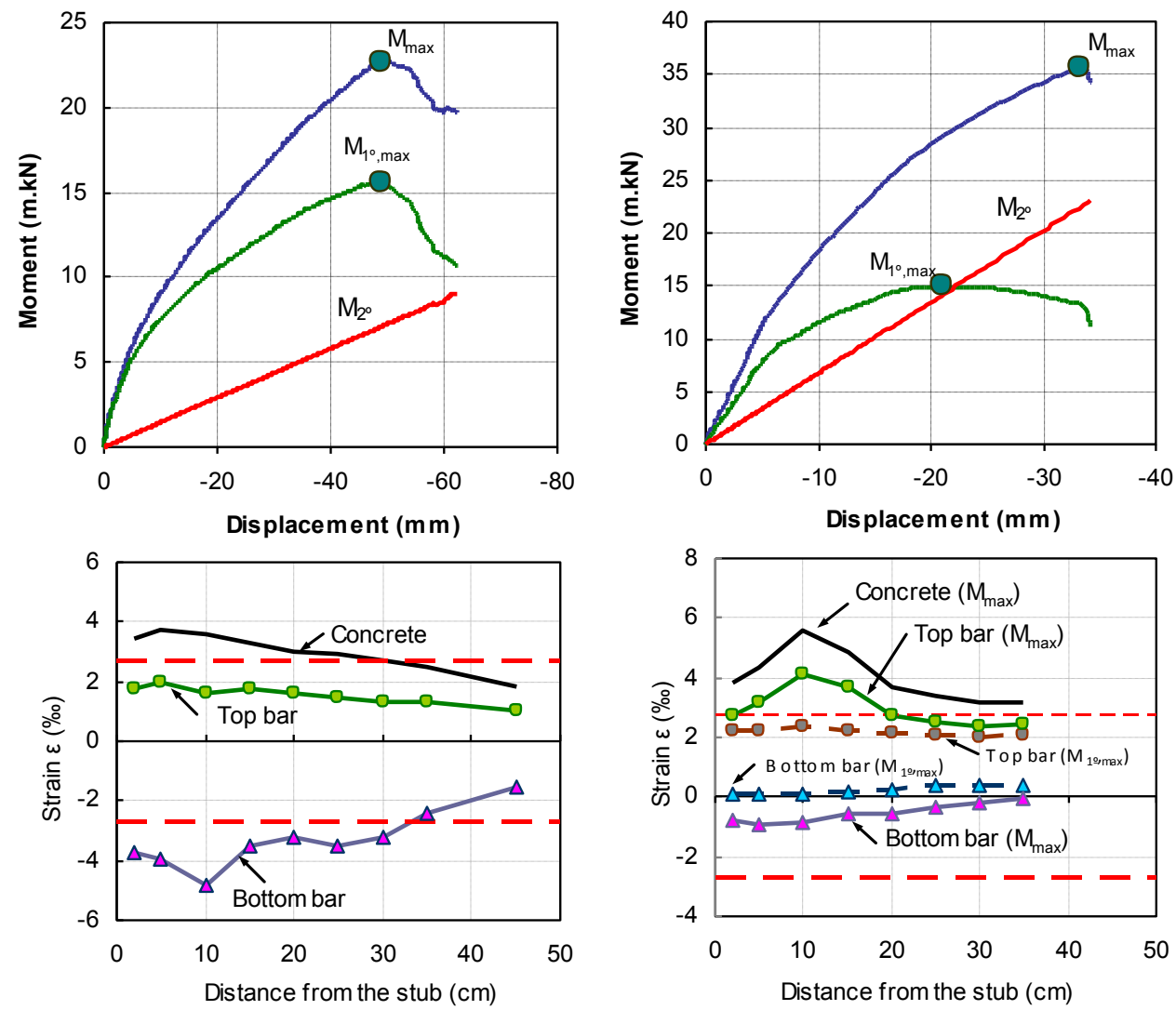

$--\cdot$ Yielding strain of longitudinal steel bars

Fig. 11. Failure mode: (a) Maximum load bending moment: failure due to tension (b) Maximum load: Instability due to compression; Maximum bending moment: Failure due to compression 


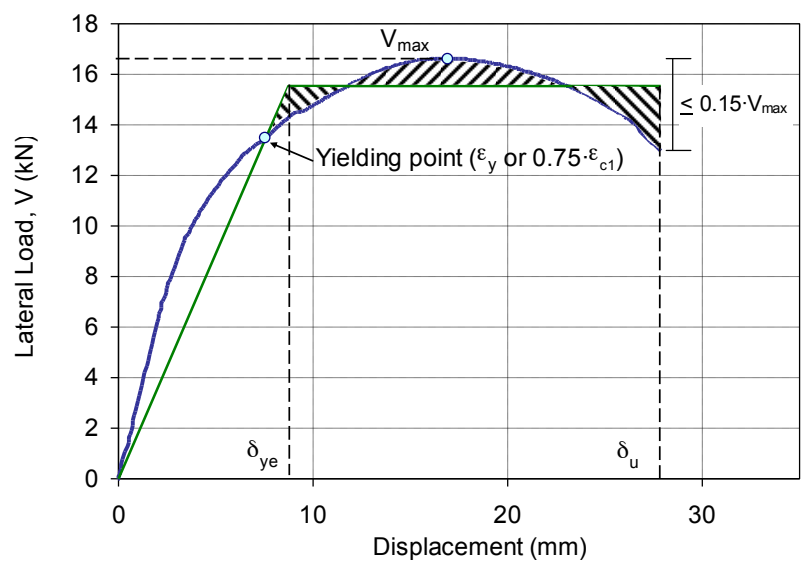

Fig. 12. Definition of the ductility factor in displacements (Test H90-10.5-C3-2-45) 


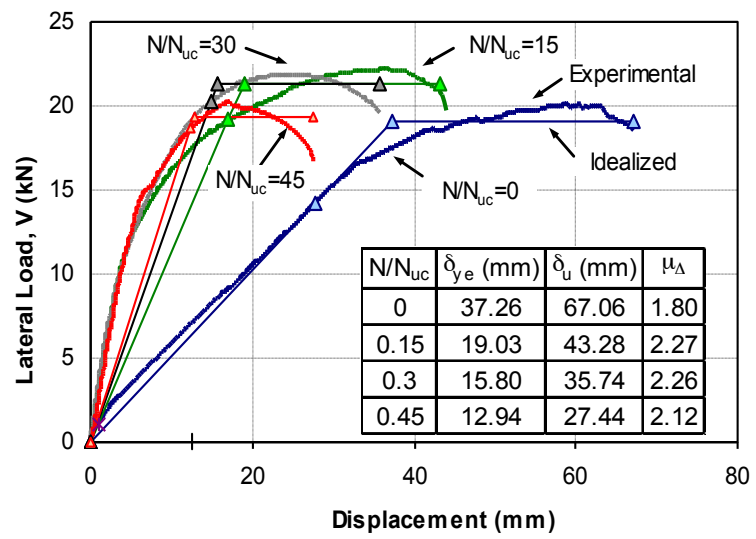

Fig. 13. Influence of the axial load level in the ductility factor in displacements $\left(\left(\lambda_{V}=10.5 ; f_{c}=90 \mathrm{MPa} ; \rho_{l}=2.3 \% ; \rho_{s} \leq 1 \%\right)\right)$ 


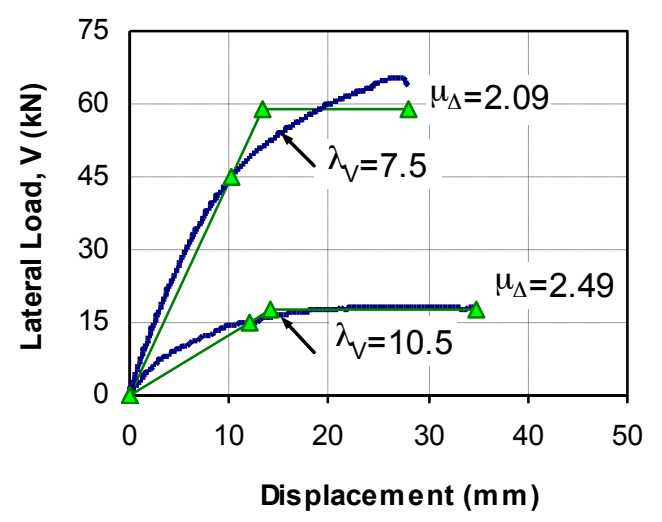

(a)

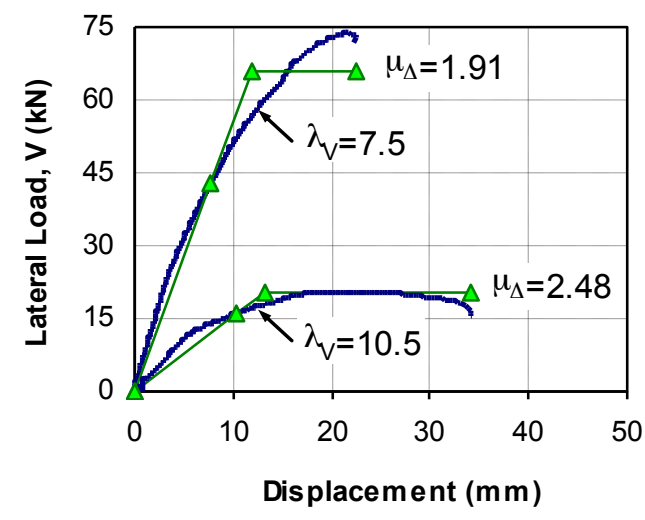

(b)

Fig. 14. Effect of the shear span ratio on the ductility (a) Axial load level N/Nuc $=30 \%$ (b) Axial load level N/Nuc $=45 \%$ 
Table 1. Types of cross-sections.

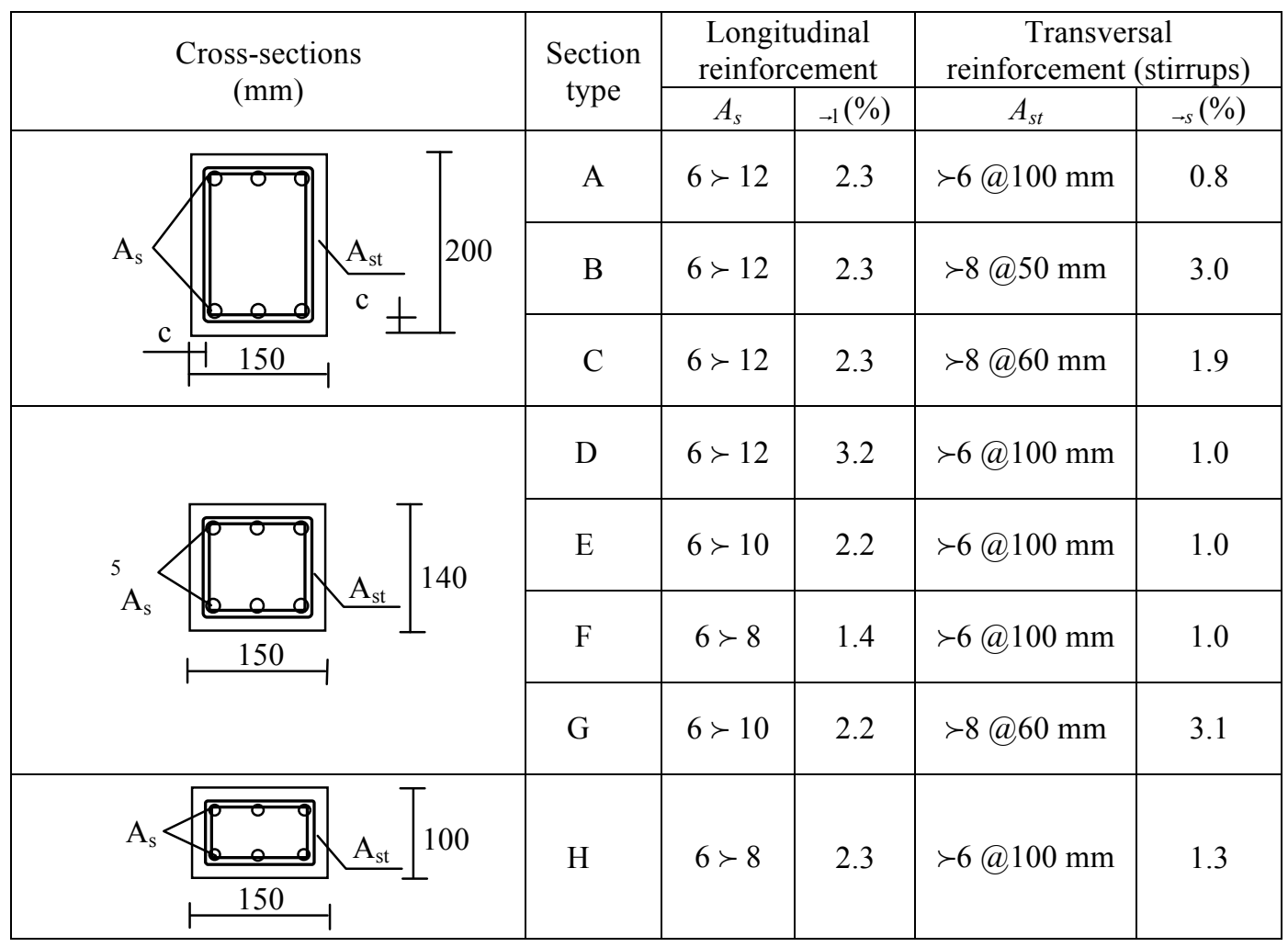

where ' $\succ$ ' means 'diameter' and '@' means 'each'. 
Table 2. Experimental tests.

\begin{tabular}{|c|c|c|c|c|c|c|c|}
\hline Ner & Test & $f_{c}(\mathrm{MPa})$ & Section type & $\lambda_{\mathrm{V}}$ & $\begin{array}{c}N \\
(\mathrm{kN})\end{array}$ & $\begin{array}{c}N_{u c} \\
(\mathrm{kN})\end{array}$ & $N / N_{u c}$ \\
\hline 1 & N30-10.5-C0-2-00 & 32.2 & $\mathrm{E}$ & 10.5 & 0 & 870 & 0.00 \\
\hline 2 & N30-10.5-C0-2-15 & 31.8 & $\mathrm{E}$ & 10.5 & 123 & 861 & 0.14 \\
\hline 3 & N30-10.5-C0-2-30 & 31.6 & $\mathrm{E}$ & 10.5 & 255 & 856 & 0.30 \\
\hline 4 & N30-10.5-C0-2-45 & 34.5 & $\mathrm{E}$ & 10.5 & 381 & 922 & 0.41 \\
\hline 5 & N30-7.5-C0-2-30 & 30.1 & $\mathrm{~A}$ & 7.5 & 350 & 1176 & 0.30 \\
\hline 6 & $\mathrm{~N} 30-7.5-\mathrm{C} 0-2-45$ & 33.0 & $\mathrm{~A}$ & 7.5 & 533 & 1271 & 0.42 \\
\hline 7 & N30-15-C0-2-30 & 32.7 & $\mathrm{H}$ & 15 & 180 & 615 & 0.29 \\
\hline 8 & N30-15-C0-2-45 & 32.9 & $\mathrm{H}$ & 15 & 265 & 618 & 0.43 \\
\hline 9 & N30-10.5-C0-1-30 & 42.2 & $\mathrm{~F}$ & 10.5 & 228 & 1021 & 0.22 \\
\hline 10 & N30-10.5-C0-1-45 & 35.2 & $\mathrm{~F}$ & 10.5 & 440 & 867 & 0.51 \\
\hline 11 & N30-10.5-C0-3-15 & 33.5 & $\mathrm{D}$ & 10.5 & 142 & 986 & 0.14 \\
\hline 12 & N30-10.5-C0-3-30 & 29.5 & $\mathrm{D}$ & 10.5 & 280 & 891 & 0.31 \\
\hline 13 & "H60-10.5-C0-2-00 & 55.8 & $\bar{E}$ & 10.5 & 0 & 1401 & 0.00 \\
\hline 14 & H60-10.5-C0-2-15 & 54.1 & $\mathrm{E}$ & 10.5 & 208 & 1363 & 0.15 \\
\hline 15 & H60-10.5-C0-2-30 & 60.5 & $\mathrm{E}$ & 10.5 & 432 & 1506 & 0.29 \\
\hline 16 & H60-10.5-C0-2-45 & 63.9 & $\mathrm{E}$ & 10.5 & 676 & 1581 & 0.43 \\
\hline 17 & H60-7.5-C0-2-30 & 63.0 & $\mathrm{~A}$ & 7.5 & 637 & 2233 & 0.29 \\
\hline 18 & H60-7.5-C0-2-45 & 67.7 & $\mathrm{~A}$ & 7.5 & 947 & 2382 & 0.40 \\
\hline 19 & $\mathrm{H} 60-15-\mathrm{C} 0-2-30$ & 58.2 & $\mathrm{H}$ & 15 & 300 & 1022 & 0.29 \\
\hline 20 & H60-15-C0-2-45 & 58.7 & $\mathrm{H}$ & 15 & 465 & 1030 & 0.45 \\
\hline 21 & H60-10.5-C0-1-15 & 57.8 & $\mathrm{~F}$ & 10.5 & 220 & 1362 & 0.16 \\
\hline 22 & H60-10.5-C0-1-30 & 58.5 & $\mathrm{~F}$ & 10.5 & 412 & 1378 & 0.30 \\
\hline 23 & H60-10.5-C0-3-15 & 58.3 & $\mathrm{D}$ & 10.5 & 238 & 1559 & 0.15 \\
\hline 24 & H60-10.5-C0-3-30 & 61.6 & $\mathrm{D}$ & 10.5 & 470 & 1634 & 0.29 \\
\hline 25 & "H90-10.5-C0-2-00 & 85.7 & $\bar{E}$ & 10.5 & 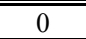 & 2053 & 0.00 \\
\hline 26 & H90-10.5-C0-2-15 & 90.5 & $\mathrm{E}$ & 10.5 & 329 & 2154 & 0.15 \\
\hline 27 & H90-10.5-C0-2-30 & 90.1 & $\mathrm{E}$ & 10.5 & 636 & 2145 & 0.30 \\
\hline 28 & H90-10.5-C0-2-45 & 93.2 & $\mathrm{E}$ & 10.5 & 972 & 2210 & 0.44 \\
\hline 29 & H90-7.5-C0-2-30 & 100.4 & $\mathrm{~A}$ & 7.5 & 914 & 3377 & 0.27 \\
\hline 30 & H90-7.5-C0-2-45 & 94.0 & $\mathrm{~A}$ & 7.5 & 1316 & 3185 & 0.41 \\
\hline 31 & H90-10.5-C0-1-15 & 90.3 & $\mathrm{~F}$ & 10.5 & 314 & 2056 & 0.15 \\
\hline 32 & H90-10.5-C0-1-30 & 96.2 & $\mathrm{~F}$ & 10.5 & 624 & 2180 & 0.29 \\
\hline 33 & H90-10.5-C0-3-15 & 89.6 & $\mathrm{D}$ & 10.5 & 340 & 2247 & 0.15 \\
\hline 34 & H90-10.5-C0-3-30 & 94.4 & $\mathrm{D}$ & 10.5 & 680 & 2347 & 0.29 \\
\hline 35 & N30-10.5-C3-2-30 & 41.0 & $\bar{G}$ & 10.5 & 258 & 1070 & 0.24 \\
\hline 36 & N30-10.5-C3-2-45 & 34.2 & $\mathrm{G}$ & 10.5 & 387 & 915 & 0.42 \\
\hline 37 & N30-7.5-C3-2-30 & 35.8 & $\mathrm{~B}$ & 7.5 & 364 & 1362 & 0.27 \\
\hline 38 & N30-7.5-C3-2-45 & 35.0 & $\mathrm{~B}$ & 7.5 & 546 & 1336 & 0.41 \\
\hline 39 & H90-10.5-C3-2-30 & 93.5 & $G$ & 10.5 & 636 & 2217 & 0.29 \\
\hline 40 & H90-10.5-C3-2-45 & 92.0 & $\mathrm{G}$ & 10.5 & 961 & 2185 & 0.44 \\
\hline 41 & H90-7.5-C3-2-30 & 86.4 & $\mathrm{~B}$ & 7.5 & 910 & 2957 & 0.31 \\
\hline 42 & H90-7.5-C3-2-45 & 78.2 & $\mathrm{~B}$ & 7.5 & 1360 & 2711 & 0.50 \\
\hline 43 & $\mathrm{H} 90-7.5-\mathrm{C} 2-2-30$ & 95.7 & $\mathrm{C}$ & 7.5 & 910 & 3236 & 0.28 \\
\hline 44 & H90-7.5-C2-2-45 & 89.2 & $\mathrm{C}$ & 7.5 & 1354 & 3041 & 0.45 \\
\hline
\end{tabular}


Table 3. Mix proportions $\left(\mathrm{kg} / \mathrm{m}^{3}\right)$.

\begin{tabular}{||c|c|c|c|c|c|c||}
\hline \hline Concrete & Cement & Sand & Gravel & Water & $\begin{array}{c}\text { Super- } \\
\text { plasticizer }\end{array}$ & Silica Fume \\
\hline $90 \mathrm{MPa}$ & 570 & 705 & 890 & 180 & 12 & 50 \\
\hline $60 \mathrm{MPa}$ & 425 & 918 & 918 & 180 & 5 & - \\
\hline $30 \mathrm{MPa}$ & 348 & 1065 & 666 & 220 & - & - \\
\hline
\end{tabular}


Table 4. Mean value and standard deviation of strength of concrete.

\begin{tabular}{||c|c|c|c||}
\hline Concrete & $\begin{array}{c}\text { Mean value } \\
f_{c}(\mathrm{MPa})\end{array}$ & $\begin{array}{c}\text { Standard } \\
\text { deviation }\end{array}$ & $\begin{array}{c}\text { Variation } \\
\text { coefficient }\end{array}$ \\
\hline $30 \mathrm{MPa}$ & 34.31 & 3.45 & $10 \%$ \\
\hline $60 \mathrm{MPa}$ & 59.83 & 3.72 & $6.2 \%$ \\
\hline $90 \mathrm{MPa}$ & 91.55 & 4.87 & $5.3 \%$ \\
\hline
\end{tabular}


Table 5. Test results.

\begin{tabular}{|c|c|c|c|c|c|c|c|c|c|c|c|c|c|c|c|}
\hline \multirow[b]{2}{*}{ Ner } & \multirow[b]{2}{*}{ Test } & \multicolumn{2}{|c|}{ Observations } & \multicolumn{5}{|c|}{ Maximum Load } & \multicolumn{5}{|c|}{ Maximum bending moment } & \multirow[b]{2}{*}{$\mu_{\mathrm{s}}$} & \multirow[b]{2}{*}{$1_{\mathrm{cr}} / \mathrm{h}$} \\
\hline & & $\begin{array}{c}\text { Reinforcing } \\
\text { bar } \\
\text { buckling }\end{array}$ & $\begin{array}{l}\text { Spalling } \\
\text { of the } \\
\text { concrete } \\
\text { cover }\end{array}$ & $\begin{array}{l}\mathrm{V}_{\max } \\
(\mathrm{kN})\end{array}$ & $\begin{array}{c}\delta_{\max } \\
(\mathrm{mm})\end{array}$ & $\begin{array}{c}\varepsilon_{s, \max } \\
(\% 0)\end{array}$ & $\begin{array}{c}\varepsilon_{s, \max }^{\prime} \\
(\% 0)\end{array}$ & $\begin{array}{l}\text { Types } \\
\text { of } \\
\text { failure } \\
(*)\end{array}$ & $\begin{array}{l}\mathrm{V}_{\mathrm{Mmax}} \\
(\mathrm{kN})\end{array}$ & $\begin{array}{l}\delta_{\mathrm{Mmax}} \\
(\mathrm{mm})\end{array}$ & $\begin{array}{c}\varepsilon_{\mathrm{s}, \mathrm{Mmax}} \\
(\% 0)\end{array}$ & $\begin{array}{c}\varepsilon_{\mathrm{s}, \mathrm{M} \max }^{\prime} \\
(\% 0)\end{array}$ & $\begin{array}{l}\text { Types } \\
\text { of } \\
\text { failure } \\
(*)\end{array}$ & & \\
\hline 1 & "N30-10.5-C0-2-00 & No & No & 17.07 & -74.53 & -11.58 & 1.00 & $\mathrm{~A} / \mathrm{T}$ & 17.07 & -74.53 & -11.58 & 1.00 & $\overline{\mathrm{A} / \mathrm{T}}$ & 2.36 & 0.50 \\
\hline 2 & N30-10.5-C0-2-15 & No & No & 18.63 & -34.16 & -7.72 & 1.23 & $\mathrm{~A} / \mathrm{T}$ & 18.61 & -34.70 & -9.61 & 1.24 & $\mathrm{~A} / \mathrm{T}$ & 2.02 & 0.86 \\
\hline 3 & $\mathrm{~N} 30-10.5-\mathrm{C} 0-2-30$ & No & Yes & 16.14 & -34.18 & -2.18 & 2.46 & $\mathrm{I} / \mathrm{E}$ & 15.23 & -42.49 & -4.26 & 3.08 & $\mathrm{~A} / \mathrm{T}$ & 3.21 & 0.57 \\
\hline 4 & $\mathrm{~N} 30-10.5-\mathrm{C} 0-2-45$ & No & Yes & 16.25 & -25.34 & -0.89 & 2.19 & $\mathrm{I} / \mathrm{E}$ & 14.48 & -29.05 & -1.34 & 2.86 & $\mathrm{~A} / \mathrm{C}$ & 2.65 & 2.00 \\
\hline 5 & N30-7.5-C0-2-30 & No & No & 55.19 & -31.13 & -4.43 & 3.75 & $\mathrm{~A} / \mathrm{T}$ & 54.87 & -32.37 & -7.72 & 4.24 & $\mathrm{~A} / \mathrm{T}$ & 2.75 & 0.50 \\
\hline 6 & N30-7.5-C0-2-45 & No & Yes & 47.40 & -21.71 & -1.35 & 5.42 & $\mathrm{~A} / \mathrm{C}$ & 45.93 & -22.84 & -1.60 & 9.47 & $\mathrm{~A} / \mathrm{C}$ & 2.36 & 1.00 \\
\hline 7 & N30-15-C0-2-30 & - & - & 4.60 & -10.93 & 0.00 & 0.80 & $\mathrm{I} / \mathrm{E}$ & 3.68 & -13.79 & -0.16 & 0.91 & - & - & - \\
\hline 8 & N30-15-C0-2-45 & - & - & 4.17 & -5.61 & 0.68 & 1.13 & $\mathrm{I} / \mathrm{E}$ & 3.45 & -6.49 & 0.67 & 1.17 & - & - & - \\
\hline 9 & $\mathrm{~N} 30-10.5-\mathrm{C} 0-1-30$ & No & No & 15.55 & -27.23 & -2.72 & 2.14 & $\mathrm{~A} / \mathrm{T}$ & 15.22 & -31.99 & -11.21 & 2.42 & $\mathrm{~A} / \mathrm{T}$ & 3.19 & 1.00 \\
\hline 10 & $\mathrm{~N} 30-10.5-\mathrm{C} 0-1-45$ & No & No & 14.74 & -16.59 & 0.29 & 2.35 & $\mathrm{~A} / \mathrm{C}$ & 13.69 & -16.96 & 0.28 & 2.42 & $\mathrm{~A} / \mathrm{C}$ & 2.75 & 1.07 \\
\hline 11 & $\mathrm{~N} 30-10.5-\mathrm{C} 0-3-15$ & No & No & 21.57 & -48.74 & -4.86 & 1.64 & $\mathrm{~A} / \mathrm{T}$ & 19.55 & -54.40 & -9.56 & 1.93 & $\mathrm{~A} / \mathrm{T}$ & 2.56 & 0.93 \\
\hline 12 & $\mathrm{~N} 30-10.5-\mathrm{C} 0-3-30$ & No & Yes & 16.57 & -42.52 & -1.81 & 3.12 & $\mathrm{~A} / \mathrm{C}$ & 15.32 & -45.21 & -1.97 & 5.06 & $\mathrm{~A} / \mathrm{C}$ & 3.07 & 1.00 \\
\hline 13 & "H60-10.5-C0-2-00 & No & No & 18.06 & \begin{tabular}{l|l|}
-53.87 \\
\end{tabular} & -11.17 & 0.19 & $\overline{\mathrm{A} / \mathrm{T}}$ & 18.06 & -53.87 & -11.17 & 0.19 & $\overline{\mathrm{A} / \mathrm{T}}$ & 2.18 & 0.57 \\
\hline 14 & $\mathrm{H} 60-10.5-\mathrm{C} 0-2-15$ & No & No & 21.39 & -38.70 & -3.94 & 1.47 & $\mathrm{I} / \mathrm{T}$ & 20.63 & -46.63 & -8.25 & 1.51 & $\mathrm{~A} / \mathrm{T}$ & 2.30 & 0.86 \\
\hline 15 & $\mathrm{H} 60-10.5-\mathrm{C} 0-2-30$ & No & Yes & 18.43 & -26.67 & -1.20 & 2.22 & $\mathrm{I} / \mathrm{E}$ & 16.56 & -34.95 & -1.85 & 2.69 & $\mathrm{~A} / \mathrm{C}$ & 2.49 & 1.61 \\
\hline 16 & $\mathrm{H} 60-10.5-\mathrm{C} 0-2-45$ & Yes & Yes & 20.62 & -20.89 & 0.06 & 2.23 & $\mathrm{I} / \mathrm{E}$ & 17.94 & -33.60 & -0.98 & 3.21 & $\mathrm{~A} / \mathrm{C}$ & 2.48 & 1.93 \\
\hline 17 & H60-7.5-C0-2-30 & No & Yes & 65.61 & -27.09 & -2.56 & 4.49 & $\mathrm{~A} / \mathrm{C}$ & 64.00 & -27.92 & -2.75 & 6.72 & $\mathrm{~A} / \mathrm{C}$ & 2.09 & 1.00 \\
\hline 18 & H60-7.5-C0-2-45 & Yes & Yes & 73.82 & -21.72 & -1.55 & 4.37 & $\mathrm{~A} / \mathrm{C}$ & 73.12 & -22.59 & -1.79 & 5.82 & $\mathrm{~A} / \mathrm{C}$ & 1.91 & 1.55 \\
\hline 19 & H60-15-C0-2-30 & - & - & 4.39 & -9.73 & 0.56 & 1.20 & $\mathrm{I} / \mathrm{E}$ & 3.76 & -15.85 & 0.05 & 1.35 & - & - & - \\
\hline 20 & $\mathrm{H} 60-15-\mathrm{C} 0-2-45$ & - & - & 2.92 & -4.80 & 1.19 & 1.56 & $\mathrm{I} / \mathrm{E}$ & 2.48 & -7.98 & 1.11 & 1.68 & - & - & - \\
\hline 21 & $\mathrm{H} 60-10.5-\mathrm{C} 0-1-15$ & No & No & 16.86 & -30.30 & -4.01 & 1.40 & $\mathrm{I} / \mathrm{T}$ & 15.07 & -40.49 & -7.21 & 1.44 & $\mathrm{~A} / \mathrm{T}$ & 2.34 & 0.86 \\
\hline 22 & $\mathrm{H} 60-10.5-\mathrm{C} 0-1-30$ & Yes & Yes & 17.23 & -24.16 & -0.62 & 2.00 & $\mathrm{I} / \mathrm{E}$ & 13.96 & -40.07 & -2.12 & 5.69 & $\mathrm{~A} / \mathrm{C}$ & 2.81 & 1.14 \\
\hline 23 & $\mathrm{H} 60-10.5-\mathrm{C} 0-3-15$ & No & No & 24.20 & -47.17 & -3.76 & 1.66 & $\mathrm{~A} / \mathrm{T}$ & 24.09 & -48.01 & -3.93 & 1.67 & $\mathrm{~A} / \mathrm{T}$ & 2.28 & 0.93 \\
\hline 24 & $\mathrm{H} 60-10.5-\mathrm{C} 0-3-30$ & Yes & Yes & 18.25 & -28.79 & -0.61 & 2.10 & $\mathrm{I} / \mathrm{E}$ & 14.99 & -51.64 & -2.87 & 5.23 & $\mathrm{~A} / \mathrm{C}$ & 3.13 & 1.50 \\
\hline 25 & "H90-10.5-C0-2-00 & No & No & 20.09 & -58.84 & -11.95 & -0.97 & $\overline{\mathrm{A} / \mathrm{T}}$ & 20.09 & -58.84 & -11.95 & -0.97 & $\overline{\mathrm{A} / \mathrm{T}}$ & 1.80 & 0.54 \\
\hline 26 & H90-10.5-C0-2-15 & No & Yes & 22.14 & -38.26 & -3.72 & 1.95 & $\mathrm{I} / \mathrm{T}$ & 20.88 & 141.27 & -6.39 & 2.02 & $\mathrm{~A} / \mathrm{T}$ & 2.27 & 0.93 \\
\hline 27 & $\mathrm{H} 90-10.5-\mathrm{C} 0-2-30$ & No & Yes & 21.90 & -25.10 & -0.94 & 1.85 & $\mathrm{I} / \mathrm{E}$ & 19.61 & 54.99 & -2.05 & 2.79 & $\mathrm{~A} / \mathrm{C}$ & 2.26 & 1.07 \\
\hline 28 & $\mathrm{H} 90-10.5-\mathrm{C} 0-2-45$ & Yes & Yes & 20.24 & -17.08 & 0.47 & 2.19 & $\mathrm{I} / \mathrm{E}$ & 39.31 & 39.31 & -0.26 & 3.20 & $\mathrm{~A} / \mathrm{C}$ & 2.12 & 1.43 \\
\hline 29 & $\mathrm{H} 90-7.5-\mathrm{C} 0-2-30$ & No & Yes & 79.10 & -25.42 & -2.23 & 4.50 & $\mathrm{~A} / \mathrm{C}$ & 78.39 & 54.07 & -2.40 & 5.49 & $\mathrm{~A} / \mathrm{C}$ & 1.88 & 0.35 \\
\hline 30 & $\mathrm{H} 90-7.5-\mathrm{C} 0-2-45$ & No & Yes & 74.65 & -19.41 & -0.60 & 5.40 & $\mathrm{~A} / \mathrm{C}$ & 73.92 & 55.55 & -0.76 & 7.35 & $\mathrm{~A} / \mathrm{C}$ & 1.72 & 0.65 \\
\hline 31 & H90-10.5-C0-1-15 & Yes & Yes & 16.47 & -26.97 & -1.52 & 1.77 & $\mathrm{I} / \mathrm{E}$ & 13.62 & 76.54 & -8.29 & 2.28 & $\mathrm{~A} / \mathrm{T}$ & 2.64 & 1.00 \\
\hline 32 & $\mathrm{H} 90-10.5-\mathrm{C} 0-1-30$ & Yes & Yes & 24.40 & -22.17 & -0.62 & 2.16 & $\mathrm{I} / \mathrm{E}$ & 21.01 & 74.08 & -1.59 & 5.07 & $\mathrm{~A} / \mathrm{C}$ & 2.46 & 1.07 \\
\hline 33 & $\mathrm{H} 90-10.5-\mathrm{C} 0-3-15$ & No & No & 27.61 & -48.03 & -3.30 & 1.34 & $\mathrm{~A} / \mathrm{T}$ & 27.36 & 80.97 & -5.65 & 1.31 & $\mathrm{~A} / \mathrm{T}$ & 1.92 & 1.00 \\
\hline 34 & H90-10.5-C0-3-30 & Yes & Yes & 25.26 & -26.78 & -1.00 & 2.06 & $\mathrm{I} / \mathrm{E}$ & 23.40 & 53.72 & -1.78 & 2.84 & $\mathrm{~A} / \mathrm{C}$ & 2.25 & 2.14 \\
\hline 35 & N30-10.5-C3-2-30 & No & Yes & 13.91 & -31.13 & -1.63 & 1.98 & $\overline{I I / E}$ & 13.02 & -46.51 & -3.06 & 5.49 & $\overline{\mathrm{A} / \mathrm{C}}$ & 3.02 & 1.14 \\
\hline 36 & $\mathrm{~N} 30-10.5-\mathrm{C} 3-2-45$ & No & Yes & 13.34 & -26.53 & -0.79 & 2.22 & $\mathrm{I} / \mathrm{E}$ & 11.98 & -34.51 & -1.77 & 4.28 & $\mathrm{~A} / \mathrm{C}$ & 3.11 & 1.43 \\
\hline 37 & N30-7.5-C3-2-30 & No & Yes & 47.93 & -31.88 & -3.35 & 10.65 & $\mathrm{~A} / \mathrm{C}$ & 47.78 & -32.51 & -3.57 & 11.99 & $\mathrm{~A} / \mathrm{C}$ & 3.30 & 1.25 \\
\hline 38 & $\mathrm{~N} 30-7.5-\mathrm{C} 3-2-45$ & No & Yes & 44.59 & -24.03 & -1.51 & 5.58 & $\mathrm{~A} / \mathrm{C}$ & 44.35 & -24.73 & -1.62 & 6.69 & $\mathrm{~A} / \mathrm{C}$ & 2.58 & 1.05 \\
\hline 39 & $\mathrm{H} 90-10.5-\mathrm{C} 3-2-30$ & No & Yes & 23.90 & -26.09 & -0.92 & 1.70 & $\mathrm{I} / \mathrm{E}$ & 21.70 & -38.04 & -1.93 & 2.00 & $\mathrm{~A} / \mathrm{C}$ & 2.21 & 1.93 \\
\hline 40 & H90-10.5-C3-2-45 & Yes & Yes & 16.62 & -16.53 & 0.55 & 2.25 & $\mathrm{I} / \mathrm{E}$ & 12.98 & -27.83 & -0.14 & 3.65 & $\mathrm{~A} / \mathrm{C}$ & 3.19 & 2.43 \\
\hline 41 & H90-7.5-C3-2-30 & No & Yes & 75.47 & -26.21 & -1.93 & 3.50 & $\mathrm{~A} / \mathrm{C}$ & 75.47 & -26.21 & -1.93 & 3.50 & $\mathrm{~A} / \mathrm{C}$ & 1.90 & 1.45 \\
\hline 42 & H90-7.5-C3-2-45 & No & Yes & 61.30 & -20.29 & -0.19 & 5.48 & $\mathrm{~A} / \mathrm{C}$ & 60.92 & -20.72 & -0.24 & 5.83 & $\mathrm{~A} / \mathrm{C}$ & 2.38 & 1.40 \\
\hline 43 & H90-7.5-C2-2-30 & No & Yes & 72.72 & -27.83 & -2.04 & 3.51 & $\mathrm{~A} / \mathrm{C}$ & 72.72 & -27.83 & -2.04 & 3.51 & $\mathrm{~A} / \mathrm{C}$ & 2.03 & 1.20 \\
\hline 44 & $\mathrm{H} 90-7.5-\mathrm{C} 2-2-45$ & No & Yes & 61.12 & -19.11 & -0.30 & 5.50 & $\mathrm{~A} / \mathrm{C}$ & 60.93 & -19.33 & -0.34 & 5.85 & $\mathrm{~A} / \mathrm{C}$ & 2.14 & 1.60 \\
\hline
\end{tabular}

$\left(^{*}\right) \quad$ I/T and IC: Instability due to yielding of the tensile reinforcement or compression reinforcement respectively; I/E: Elastic instability; A/T: Tension failure; A/C: Compression failure. 
Table 6. Failure mode. Influence of the axial load level, strength of concrete and shear span ratio $(\rho \mathrm{l}=2.3 \% ; \rho s \leq 1 \%)$.

\begin{tabular}{|c|c|c|c|c|c|c|c|c|c|c|c|c|c|c|c|c|}
\hline & & \multicolumn{9}{|c|}{ Maximum Load } & \multicolumn{6}{|c|}{ Maximum bending moment } \\
\hline & & \multicolumn{3}{|c|}{$\lambda_{V}=7.5$} & \multicolumn{3}{|c|}{$\lambda_{V}=10.5$} & \multicolumn{3}{|c|}{$\lambda_{\mathrm{V}}=15$} & \multicolumn{3}{|c|}{$\lambda_{\mathrm{V}}=7.5$} & \multicolumn{3}{|c|}{$\lambda_{V}=10.5$} \\
\hline & $f_{c}(\mathrm{MPa})$ & 30 & 60 & 90 & 30 & 60 & 90 & 30 & 60 & 90 & 30 & 60 & 90 & 30 & 60 & 90 \\
\hline \multirow{4}{*}{$\mathrm{N} / \mathrm{N}_{\mathrm{uc}}$} & 0 & - & - & - & $\mathrm{A} / \mathrm{T}$ & $\mathrm{A} / \mathrm{T}$ & $\mathrm{A} / \mathrm{T}$ & - & - & - & - & - & - & $\mathrm{A} / \mathrm{T}$ & $\mathrm{A} / \mathrm{T}$ & $\mathrm{A} / \mathrm{T}$ \\
\hline & 0.15 & - & - & - & $\mathrm{A} / \mathrm{T}$ & $\mathrm{I} / \mathrm{T}$ & $\mathrm{I} / \mathrm{T}$ & & & - & - & - & - & $\mathrm{A} / \mathrm{T}$ & $\mathrm{A} / \mathrm{T}$ & $\mathrm{A} / \mathrm{T}$ \\
\hline & 0.3 & $\mathrm{~A} / \mathrm{T}$ & $\mathrm{A} / \mathrm{C}$ & $\mathrm{A} / \mathrm{C}$ & $\mathrm{I} / \mathrm{E}$ & $\mathrm{I} / \mathrm{E}$ & $\mathrm{I} / \mathrm{E}$ & $\mathrm{I} / \mathrm{E}$ & $\mathrm{I} / \mathrm{E}$ & - & $\mathrm{A} / \mathrm{T}$ & $\mathrm{A} / \mathrm{C}$ & $\mathrm{A} / \mathrm{C}$ & $\mathrm{A} / \mathrm{T}$ & $\mathrm{A} / \mathrm{C}$ & $\mathrm{A} / \mathrm{C}$ \\
\hline & 0.45 & $\mathrm{~A} / \mathrm{C}$ & $\mathrm{A} / \mathrm{C}$ & $\mathrm{A} / \mathrm{C}$ & $\mathrm{I} / \mathrm{E}$ & $\mathrm{I} / \mathrm{E}$ & $\mathrm{I} / \mathrm{E}$ & $\mathrm{I} / \mathrm{E}$ & $\mathrm{I} / \mathrm{E}$ & - & $\mathrm{A} / \mathrm{C}$ & $\mathrm{A} / \mathrm{C}$ & $\mathrm{A} / \mathrm{C}$ & $\mathrm{A} / \mathrm{C}$ & $\mathrm{A} / \mathrm{C}$ & $\mathrm{A} / \mathrm{C}$ \\
\hline
\end{tabular}

Table 7. Failure mode. Influence of the longitudinal reinforcement ratio and strength of concrete $\left(\lambda_{V}=10.5 ; \rho s \leq 1 \%\right)$

\begin{tabular}{|c|c|c|c|c|c|c|c|c|c|c|c|c|c|}
\hline & \multirow{3}{*}{$\frac{\mathrm{f}_{\mathrm{c}}(\mathrm{MPa})}{\mathrm{N} / \mathrm{N}_{\mathrm{uc}}}$} & \multicolumn{6}{|c|}{ Maximum Load } & \multicolumn{6}{|c|}{ Maximum bending moment } \\
\hline & & \multicolumn{4}{|c|}{\begin{tabular}{l|l} 
& 60 \\
\end{tabular}} & \multicolumn{2}{|c|}{90} & \multicolumn{2}{|c|}{30} & \multicolumn{2}{|c|}{60} & \multicolumn{2}{|c|}{90} \\
\hline & & 0.15 & 0.3 & 0.15 & 0.3 & 0.15 & 0.3 & 0.15 & 0.3 & 0.15 & 0.3 & 0.15 & 0.3 \\
\hline \multirow{3}{*}{$\rho_{1}(\%)$} & 1.4 & - & $\mathrm{A} / \mathrm{T}$ & $\mathrm{I} / \mathrm{T}$ & $\mathrm{I} / \mathrm{E}$ & $\mathrm{I} / \mathrm{E}$ & $\mathrm{I} / \mathrm{E}$ & - & $\mathrm{A} / \mathrm{T}$ & $\mathrm{A} / \mathrm{T}$ & $\mathrm{A} / \mathrm{C}$ & $\mathrm{A} / \mathrm{T}$ & $\mathrm{A} / \mathrm{C}$ \\
\hline & 2.3 & $\mathrm{~A} / \mathrm{T}$ & $\mathrm{I} / \mathrm{E}$ & $\mathrm{I} / \mathrm{T}$ & $\mathrm{I} / \mathrm{E}$ & $\mathrm{I} / \mathrm{T}$ & $\mathrm{I} / \mathrm{E}$ & $\mathrm{A} / \mathrm{T}$ & $\mathrm{A} / \mathrm{T}$ & $\mathrm{A} / \mathrm{T}$ & $\mathrm{A} / \mathrm{C}$ & $\mathrm{A} / \mathrm{T}$ & $\mathrm{A} / \mathrm{C}$ \\
\hline & 3.2 & $\mathrm{~A} / \mathrm{T}$ & $\mathrm{A} / \mathrm{C}$ & $\mathrm{A} / \mathrm{T}$ & $\mathrm{I} / \mathrm{E}$ & $\mathrm{A} / \mathrm{T}$ & $\mathrm{I} / \mathrm{E}$ & $\mathrm{A} / \mathrm{T}$ & $\mathrm{A} / \mathrm{C}$ & $\mathrm{A} / \mathrm{T}$ & $\mathrm{A} / \mathrm{C}$ & $\mathrm{A} / \mathrm{T}$ & $\mathrm{A} / \mathrm{C}$ \\
\hline
\end{tabular}

Table 8. Failure mode. Influence of the transversal reinforcement ratio, strength of concrete and shear span ratio $(\rho \mathrm{l}=2.3 \%)$

\begin{tabular}{|c|c|c|c|c|c|c|c|c|c|c|c|c|c|c|c|c|c|}
\hline \multirow{4}{*}{\begin{tabular}{|c}
\multicolumn{1}{l}{$\mathrm{f}_{\mathrm{c}}$} \\
$(\mathrm{MPa})$ \\
$\mathrm{N} / \mathrm{N}$
\end{tabular}} & \multicolumn{9}{|c|}{ Maximum Load } & \multicolumn{8}{|c|}{ Maximum bending moment } \\
\hline & \multicolumn{5}{|c|}{$\lambda_{\mathrm{V}}=7.5$} & \multicolumn{4}{|c|}{$\lambda_{V}=10.5$} & \multicolumn{4}{|c|}{$\lambda_{V}=7.5$} & \multicolumn{4}{|c|}{$\lambda_{V}=10.5$} \\
\hline & \multicolumn{3}{|c|}{30} & \multicolumn{2}{|c|}{90} & \multicolumn{2}{|c|}{30} & \multicolumn{2}{|c|}{90} & \multicolumn{2}{|c|}{30} & \multicolumn{2}{|c|}{90} & \multicolumn{2}{|c|}{30} & \multicolumn{2}{|c|}{90} \\
\hline & & 0.3 & 0.45 & 0.3 & 0.45 & 0.3 & 0.45 & 0.3 & 0.45 & 0.3 & 0.45 & 0.3 & 0.45 & 0.3 & 0.45 & 0.3 & 0.45 \\
\hline & & $\mathrm{A} / \mathrm{T}$ & $\mathrm{A} / \mathrm{C}$ & $\mathrm{A} / \mathrm{C}$ & $\mathrm{A} / \mathrm{C}$ & $\mathrm{I} / \mathrm{E}$ & $\mathrm{I} / \mathrm{E}$ & $\mathrm{I} / \mathrm{E}$ & $\mathrm{I} / \mathrm{E}$ & $\mathrm{A} / \mathrm{T}$ & $\mathrm{A} / \mathrm{C}$ & $\mathrm{A} / \mathrm{C}$ & $\mathrm{A} / \mathrm{C}$ & $\mathrm{A} / \mathrm{T}$ & $\mathrm{A} / \mathrm{C}$ & $\mathrm{A} / \mathrm{C}$ & $\mathrm{A} / \mathrm{C}$ \\
\hline & & - & - & $\mathrm{A} / \mathrm{C}$ & $\mathrm{A} / \mathrm{C}$ & - & - & - & - & - & - & $\mathrm{A} / \mathrm{C}$ & $\mathrm{A} / \mathrm{C}$ & - & - & - & - \\
\hline & & $\overline{\mathrm{A} / \mathrm{C}}$ & $\mathrm{A} / \mathrm{C}$ & $\mathrm{A} / \mathrm{C}$ & $\mathrm{A} / \mathrm{C}$ & $\mathrm{I} / \mathrm{E}$ & $\mathrm{I} / \mathrm{E}$ & $\mathrm{I} / \mathrm{E}$ & $\mathrm{I} / \mathrm{E}$ & $\mathrm{A} / \mathrm{C}$ & $\mathrm{A} / \mathrm{C}$ & $\mathrm{A} / \mathrm{C}$ & $\mathrm{A} / \mathrm{C}$ & $\mathrm{A} / \mathrm{C}$ & $\mathrm{A} / \mathrm{C}$ & $\mathrm{A} / \mathrm{C}$ & $\mathrm{A} / \mathrm{C}$ \\
\hline
\end{tabular}


Table 9. Ductility in displacements. Influence of the axial load level, strength of concrete and shear span ratio $(\rho \mathrm{l}=2.3 \% ; \rho s \leq 1 \%)$.

\begin{tabular}{|c|c|c|c|c|c|c|c|}
\hline & \multirow[b]{2}{*}{$\mathrm{f}_{\mathrm{c}}(\mathrm{MPa})$} & \multicolumn{3}{|c|}{$\lambda_{V}=7,5$} & \multicolumn{3}{|c|}{$\lambda_{V}=10,5$} \\
\hline & & 30 & 60 & 90 & 30 & 60 & 90 \\
\hline \multirow{4}{*}{$\mathrm{N} / \mathrm{N}_{\mathrm{uc}}$} & 0 & - & - & - & 2.36 & 2.18 & 1.80 \\
\hline & 0.15 & - & - & - & 2.02 & 2.30 & 2.27 \\
\hline & 0.3 & 2.75 & 2.09 & 1.88 & 3.21 & 2.49 & 2.26 \\
\hline & 0.45 & 2.36 & 1.91 & 1.72 & 2.65 & 2.48 & 2.12 \\
\hline
\end{tabular}

Table 10. Ductility in displacements. Influence of the longitudinal reinforcement ratio and the strength of concrete $\left(\lambda_{\mathrm{V}}=10.5 ; \rho \mathrm{s} \leq 1 \%\right)$

\begin{tabular}{|c|c|c|c|c|c|c|c|}
\hline & \multirow[b]{3}{*}{$\mathrm{N} / \mathrm{N}_{\mathrm{uc}}$} & \multicolumn{6}{|c|}{$\mathrm{f}_{\mathrm{c}}(\mathrm{MPa})$} \\
\hline & & \multicolumn{2}{|c|}{30} & \multicolumn{2}{|c|}{60} & \multicolumn{2}{|c|}{90} \\
\hline & & 0.15 & 0.3 & 0.15 & 0.3 & 0.15 & 0.3 \\
\hline \multirow{3}{*}{$\rho_{1}(\%)$} & 1.4 & - & 3.19 & 2.34 & 2.81 & 2.64 & 2.46 \\
\hline & 2.3 & 2.02 & 3.21 & 2.30 & 2.49 & 2.27 & 2.26 \\
\hline & 3.2 & 2.56 & 3.07 & 2.28 & 2.25 & 1.92 & 2.25 \\
\hline
\end{tabular}

Table 11. Ductility in displacements. Influence of the transversal reinforcement ratio, strength of concrete and shear span ratio $(\rho \mathrm{l}=2.3 \%)$

\begin{tabular}{|c|c|c|c|c|c|c|c|c|c|}
\cline { 2 - 10 } \multicolumn{1}{c|}{} & \multicolumn{4}{c|}{$\lambda_{\mathrm{V}}=7,5$} & \multicolumn{4}{c|}{$\lambda_{\mathrm{V}}=10,5$} \\
\hline \multicolumn{2}{c|}{$\mathrm{f}_{\mathrm{c}}(\mathrm{MPa})$} & \multicolumn{2}{|c|}{30} & \multicolumn{2}{c|}{90} & \multicolumn{3}{|c|}{30} & \multicolumn{2}{|c|}{90} \\
\hline $\mathrm{N} / \mathrm{N}_{\mathrm{uc}}$ & 0.3 & 0.45 & 0.3 & 0.45 & 0.3 & 0.45 & 0.3 & 0.45 \\
\hline \multirow{3}{*}{$\rho_{\mathrm{s}}(\%)$} & 1 & 2.75 & 2.36 & 1.88 & 1.72 & 3.21 & 2.65 & 2.26 & 2.12 \\
\cline { 2 - 11 } & 2 & - & - & 2.03 & 2.03 & - & - & - & - \\
\cline { 2 - 10 } & 3 & 3.30 & 2.58 & 1.90 & 2.38 & 3.02 & 3.11 & 2.21 & 3.19 \\
\hline
\end{tabular}


Table 12. Verification of the simplified methods.

\begin{tabular}{|c|c|c|c|c|c|c|c|c|c|c|c|}
\hline Ner & Test & $\begin{array}{l}\mathrm{V}_{\max } \\
(\mathrm{kN})\end{array}$ & $\begin{array}{l}\mathrm{V}_{\mathrm{EC}-2} \\
(\mathrm{kN})\end{array}$ & $\begin{array}{c}\mathrm{V}_{\text {ACI-318 }} \\
(\mathrm{kN})\end{array}$ & $\xi_{\mathrm{V}, \mathrm{EC}-2}$ & $\xi_{\mathrm{V}, \mathrm{ACI}}$ & $\begin{array}{c}\mathrm{M}_{\max } \\
(\mathrm{mkN})\end{array}$ & $\begin{array}{l}\mathrm{M}_{\mathrm{EC}-2} \\
(\mathrm{mkN})\end{array}$ & $\begin{array}{c}\mathrm{M}_{\mathrm{ACI}-318} \\
(\mathrm{mkN})\end{array}$ & $\xi_{\mathrm{M}, \mathrm{EC}-2}$ & $\xi_{\mathrm{M}, \mathrm{ACI}-318}$ \\
\hline 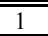 & N30-10.5-C0-2-00 & 17.07 & 17.11 & 16.91 & 1.00 & 1.01 & 12.36 & 11.05 & 10.88 & 1.12 & 1.14 \\
\hline 2 & $\mathrm{~N} 30-10.5-\mathrm{C} 0-2-15$ & 18.63 & 15.96 & 15.09 & 1.17 & 1.23 & 17.56 & 16.19 & 15.67 & 1.08 & 1.12 \\
\hline 3 & N30-10.5-C0-2-30 & 16.14 & 10.94 & 7.59 & 1.47 & 2.13 & 22.12 & 18.85 & 15.77 & 1.17 & 1.40 \\
\hline 4 & $\mathrm{~N} 30-10.5-\mathrm{C} 0-2-45$ & 16.25 & - & - & - & - & 21.61 & 18.79 & 15.35 & 1.15 & 1.41 \\
\hline 5 & $\mathrm{~N} 30-7.5-\mathrm{C} 0-2-30$ & 55.19 & 45.99 & 38.71 & 1.20 & 1.43 & 49.34 & 45.27 & 38.11 & 1.09 & 1.29 \\
\hline 6 & $\mathrm{~N} 30-7.5-\mathrm{C} 0-2-45$ & 47.4 & 37.82 & 30.22 & 1.25 & 1.57 & 45.89 & 43.81 & 36.03 & 1.05 & 1.27 \\
\hline 7 & N30-15-C0-2-30 & 4.6 & - & - & - & - & - & - & - & & \\
\hline 8 & N30-15-C0-2-45 & 4.17 & - & - & - & - & - & - & - & & \\
\hline 9 & $\mathrm{~N} 30-10.5-\mathrm{C} 0-1-30$ & 15.55 & 11.28 & 7.94 & 1.38 & 1.96 & 18.35 & 16.89 & 16.08 & 1.09 & 1.14 \\
\hline 10 & N30-10.5-C0-1-45 & 14.74 & - & - & - & - & 17.99 & 15.55 & 12.34 & 1.16 & 1.46 \\
\hline 11 & $\mathrm{~N} 30-10.5-\mathrm{C} 0-3-15$ & 21.57 & 21.21 & 20.25 & 1.02 & 1.06 & 22.75 & 21.49 & 20.80 & 1.06 & 1.09 \\
\hline 12 & N30-10.5-C0-3-30 & 16.57 & 12.68 & 9.62 & 1.31 & 1.72 & 24.5 & 21.16 & 17.67 & 1.16 & 1.39 \\
\hline 13 & "H60-10.5-C0-2-00 & 18.06 & 18.07 & 17.86 & 1.00 & 1.01 & 12.45 & 11.86 & 11.58 & 1.05 & 1.07 \\
\hline 14 & $\mathrm{H} 60-10.5-\mathrm{C} 0-2-15$ & 21.39 & 18.19 & 15.42 & 1.18 & 1.39 & 24.54 & 20.97 & 20.58 & 1.17 & 1.19 \\
\hline 15 & $\mathrm{H} 60-10.5-\mathrm{C} 0-2-30$ & 18.43 & 10.90 & 2.36 & 1.69 & 7.81 & 28.05 & 25.13 & 22.97 & 1.12 & 1.22 \\
\hline 16 & $\mathrm{H} 60-10.5-\mathrm{C} 0-2-45$ & 20.62 & - & - & - & - & 35.72 & 24.80 & 23.41 & 1.44 & 1.53 \\
\hline 17 & $\mathrm{H} 60-7.5-\mathrm{C} 0-2-30$ & 65.61 & 53.24 & 44.83 & 1.23 & 1.46 & 64.93 & 58.15 & 54.70 & 1.12 & 1.19 \\
\hline 18 & H60-7.5-C0-2-45 & 73.82 & 42.43 & 31.88 & 1.74 & 2.32 & 74.35 & 57.36 & 55.92 & 1.30 & 1.33 \\
\hline 19 & H60-15-C0-2-30 & 4.39 & - & - & - & - & - & - & - & & \\
\hline 20 & H60-15-C0-2-45 & 2.92 & - & - & - & - & - & - & - & & \\
\hline 21 & H60-10.5-C0-1-15 & 16.86 & 14.26 & 10.64 & 1.18 & 1.59 & 20.3 & 17.72 & 17.41 & 1.15 & 1.17 \\
\hline 22 & H60-10.5-C0-1-30 & 17.23 & 8.16 & & 2.11 & & 27.34 & 22.31 & 20.04 & 1.23 & 1.36 \\
\hline 23 & $\mathrm{H} 60-10.5-\mathrm{C} 0-3-15$ & 24.2 & 23.27 & 19.98 & 1.04 & 1.21 & 29.02 & 26.72 & 25.89 & 1.09 & 1.12 \\
\hline 24 & H60-10.5-C0-3-30 & 18.25 & 12.91 & 5.06 & 1.41 & 3.61 & 35.19 & 28.00 & 25.97 & 1.26 & 1.35 \\
\hline 25 & "H90-10.5-C0-2-00 & 20.09 & 18.59 & 18.77 & 1.08 & 1.07 & 1414.49 & 12.35 & 1212.27 & 1.17 & 1.18 \\
\hline 26 & $\mathrm{H} 90-10.5-\mathrm{C} 0-2-15$ & 22.14 & 21.33 & 14.35 & 1.04 & 1.54 & 28.73 & 27.30 & 27.58 & 1.05 & 1.04 \\
\hline 27 & $\mathrm{H} 90-10.5-\mathrm{C} 0-2-30$ & 21.9 & 9.33 & - & 2.35 & - & 36.93 & 30.64 & 31.63 & 1.21 & 1.17 \\
\hline 28 & H90-10.5-C0-2-45 & 20.24 & - & - & - & - & 39 & 30.58 & 32.33 & 1.28 & 1.21 \\
\hline 29 & $\mathrm{H} 90-7.5-\mathrm{C} 0-2-30$ & 79.1 & 63.38 & 51.55 & 1.25 & 1.53 & 80.76 & 73.03 & 76.49 & 1.11 & 1.06 \\
\hline 30 & $\mathrm{H} 90-7.5-\mathrm{C} 0-2-45$ & 74.65 & 44.51 & 25.75 & 1.68 & 2.90 & 79.73 & 68.47 & 72.23 & 1.16 & 1.10 \\
\hline 31 & $\mathrm{H} 90-10.5-\mathrm{C} 0-1-15$ & 16.47 & 17.43 & 10.07 & 0.94 & 1.63 & 24.81 & 22.87 & 23.06 & 1.08 & 1.08 \\
\hline 32 & $\mathrm{H} 90-10.5-\mathrm{C} 0-1-30$ & 24.4 & - & - & - & - & 36.77 & 29.70 & 30.70 & 1.24 & 1.20 \\
\hline 33 & $\mathrm{H} 90-10.5-\mathrm{C} 0-3-15$ & 27.61 & 25.82 & 19.54 & 1.07 & 1.41 & 36.66 & 32.07 & 32.46 & 1.14 & 1.13 \\
\hline 34 & H90-10.5-C0-3-30 & 25.26 & 11.79 & - & 2.14 & - & 41.17 & 34.07 & 35.56 & 1.21 & 1.16 \\
\hline 35 & "N30-10.5-C3-2-30 & 13.91 & 12.93 & 8.28 & 1.08 & 1.68 & 21.46 & 20.58 & 17.49 & 1.04 & 1.23 \\
\hline 36 & N30-10.5-C3-2-45 & 13.34 & - & - & - & - & 22.05 & 17.51 & 14.34 & 1.26 & 1.54 \\
\hline 37 & N30-7.5-C3-2-30 & 47.93 & 46.92 & 39.98 & 1.02 & 1.20 & 46.45 & 46.27 & 40.12 & 1.00 & 1.16 \\
\hline 38 & $\mathrm{~N} 30-7.5-\mathrm{C} 3-2-45$ & 44.59 & 37.23 & 29.09 & 1.20 & 1.53 & 45.67 & 44.04 & 36.06 & 1.04 & 1.27 \\
\hline 39 & $\mathrm{H} 90-10.5-\mathrm{C} 3-2-30$ & 23.9 & 9.08 & - & 2.63 & - & 39.92 & 30.51 & 31.56 & 1.31 & 1.26 \\
\hline 40 & H90-10.5-C3-2-45 & 16.62 & - & - & - & - & 36.14 & 29.69 & 31.27 & 1.22 & 1.16 \\
\hline 41 & $\mathrm{H} 90-7.5-\mathrm{C} 3-2-30$ & 75.47 & 53.26 & 41.68 & 1.42 & 1.81 & 78.52 & 65.08 & 67.07 & 1.21 & 1.17 \\
\hline 42 & $\mathrm{H} 90-7.5-\mathrm{C} 3-2-45$ & 61.3 & 29.81 & 12.84 & 2.06 & 4.77 & 72.35 & 55.26 & 57.15 & 1.31 & 1.27 \\
\hline 43 & H90-7.5-C2-2-30 & 72.72 & 58.83 & 46.49 & 1.24 & 1.56 & 77.63 & 69.46 & 72.34 & 1.12 & 1.07 \\
\hline 44 & H90-7.5-C2-2-45 & 61.12 & 37.97 & 18.25 & 1.61 & 3.35 & 70.42 & 63.70 & 66.95 & 1.11 & 1.05 \\
\hline & Average error & - & - & - & 1.40 & 2.02 & - & - & - & 1.16 & 1.22 \\
\hline
\end{tabular}


Table 13. Verification of the design codes

\begin{tabular}{|c|c|c|c|c|c|c|c|c|c|}
\hline & & \multicolumn{4}{|c|}{$\mathrm{V}_{\max }$} & \multicolumn{4}{|c|}{$\mathrm{M}_{\max }$} \\
\hline & & \multicolumn{2}{|c|}{ EC-2 (2004) } & \multicolumn{2}{|c|}{ ACI-318 (08) } & \multicolumn{2}{|c|}{ EC-2 (2004) } & \multicolumn{2}{|c|}{ ACI-318 (08) } \\
\hline & & Average & $\begin{array}{l}\mathrm{VC} \\
(\%)\end{array}$ & Average & $\begin{array}{l}\mathrm{VC} \\
(\%)\end{array}$ & Average & $\begin{array}{l}\mathrm{VC} \\
(\%)\end{array}$ & Average & $\begin{array}{l}\mathrm{VC} \\
(\%)\end{array}$ \\
\hline \multirow{3}{*}{$\begin{array}{c}\mathrm{f}_{\mathrm{c}} \\
(\mathrm{MPa})\end{array}$} & 30 & 1.19 & 13.11 & 1.50 & 23.89 & 1.10 & 6.21 & 1.28 & 11.03 \\
\hline & 60 & 1.40 & 26.77 & 2.55 & 89.58 & 1.19 & 9.84 & 1.25 & 10.93 \\
\hline & 90 & 1.58 & 35.27 & 2.16 & 53.62 & 1.18 & 6.59 & 1.14 & 6.28 \\
\hline \multirow{4}{*}{$\mathrm{N} / \mathrm{N}_{\mathrm{uc}}$} & 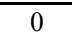 & 1.03 & 4.63 & $\begin{array}{c}1.03 \\
\end{array}$ & 3.36 & $\overline{c 1.11}$ & $\overline{c 5.56}$ & 1.13 & 4.70 \\
\hline & 0.15 & 1.08 & 8.07 & 1.38 & 14.53 & 1.10 & 3.97 & 1.12 & 4.30 \\
\hline & 0.3 & 1.56 & 31.18 & 2.33 & \begin{tabular}{|l|}
78.89 \\
\end{tabular} & 1.16 & 7.01 & 1.22 & 8.57 \\
\hline & 0.45 & 1.59 & 20.20 & 2.74 & 44.82 & 1.20 & 9.77 & 1.30 & 12.22 \\
\hline \multirow{2}{*}{$\lambda_{\mathrm{V}}$} & 7.5 & 1.41 & 21.32 & 2.12 & 50.00 & 1.13 & 8.46 & 1.19 & 8.37 \\
\hline & 10.5 & 1.39 & 35.77 & 1.95 & 83.95 & 1.17 & 7.81 & 1.23 & 11.38 \\
\hline \multirow{3}{*}{$\begin{array}{c}\rho_{1} \\
(\%)\end{array}$} & $\bar{~} 1.4$ & 1.33 & 32.15 & $\overline{c 1.80}$ & $\mid$\begin{tabular}{|l|l|}
57.54 \\
\end{tabular} & $\overline{c 1.15}$ & $\overline{c 6.42}$ & 1.21 & 10.66 \\
\hline & 2.3 & 1.42 & 31.07 & 2.11 & 75.08 & 1.16 & 8.88 & 1.22 & 10.79 \\
\hline & 3.2 & 1.33 & 32.15 & 1.80 & 57.54 & 1.15 & 6.42 & 1.21 & 10.66 \\
\hline \multirow{3}{*}{$\begin{array}{c}\rho_{\mathrm{s}} \\
(\%)\end{array}$} & 1 & 1.36 & 28.58 & 1.94 & \begin{tabular}{|l|l|}
75.15 \\
\end{tabular} & 1.16 & 7.49 & 1.22 & 10.67 \\
\hline & 2 & 1.42 & 18.57 & 2.46 & \begin{tabular}{|l|l|}
51.37 \\
\end{tabular} & 1.11 & 0.77 & 1.06 & 1.42 \\
\hline & 3 & 1.57 & 41.10 & 2.20 & 66.26 & 1.17 & 10.76 & 1.26 & 9.86 \\
\hline \multicolumn{2}{|c|}{ Total } & 1.40 & 30.86 & 2.02 & 69.62 & 1.16 & 8.01 & 1.22 & 10.66 \\
\hline
\end{tabular}

